\title{
Exploring the relationship between Australian university websites andinternational student enrolments
}

\begin{abstract}
Purpose - This paper focuses on exploring the relationship between Australian university websites and international student enrolments. Few studies have investigated this relationship and, as such, this research addresses some of the existing knowledge gaps.
\end{abstract}

Design/methodology/approach - A mono-method qualitative methodology was adopted for this study. Primary data collection was through the website content of selected Australian universities. Six Australian universities were selected: three universities with positive international student enrolments and three universities with negative international student enrolments. The website content of the selected six universities was analysed using the dimensions of the ICTRT framework (Li and Wang, 2011) to evaluate website effectiveness. The study results were based on two analysis levels, an overall thematic analysis (level 1) and an ICTRT framework-based analysis (level 2). The thematic analysis, based on the major themes and concepts, was conducted using Leximancer 4.5.

Findings - Two major findings emerged. First, the websites of universities with positive international student enrolments tend to be more people focused whereas websites from universities with negative international student enrolments tend to be technology or system focused. Second, websites from universities with positive international student enrolments tend to be more visionary or forward focused whereas websites from universities with negative international student enrolments tend to be more backward focused. Additionally, the study findings indicate some important website marketing strategies for Australian universities with negative international student enrolments.

Research limitations/implications - This study used ICTRT framework to evaluate the websites of Australian universities. Li and Wang (2011) proposed this framework for evaluating websites. Hotel, travel agency and destination marketing organisation websites have been assessed using the ICTRT framework (Li and Wang, 2011; Pai et al., 2014; Sun et al., 2017). 
This model has not previously been used, however, to evaluate tertiary education websites. This study is among the first to examine the university websites using a theoretical framework employed in destination marketing organisations which is a major theoretical contribution.

Practical implications - The major findings indicate that the website attributes, which are future focused, and people oriented, are necessary for university websites with negative international student enrolments. Similar to university websites with positive international student enrolments, university websites with negative international student enrolments should also provide more contact details of staff members, should be more people oriented and should provide information focused on future students rather than past and current students. These practical implications are useful for administrative bodies in Australian universities for increasing international student enrolments.

Originality/value - This study is among the first to examine the university websites using a theoretical framework used in destination marketing organizations which is a major theoretical contribution. For example, this study has provided an illustrative example of how a research model of destination marketing organizations will be used in the universities or higher education context.

Keywords- Australian higher education sector, ICTRT framework, international student enrolments, University websites, Website marketing strategies

Paper type - Research paper

\section{Introduction}

International higher education is a major growth industry worldwide (Brown \& Mazzarol, 2009). Universities and colleges are striving to increase their student recruitment and advertising campaigns to attract most eligible applicants to their campuses. International education is Australia's largest service export and third largest export. In 2016, on-shore international students represented 21.1 percent and domestic enrolments accounted for 78.8 percent of total enrolments in Australia. ${ }^{1}$ In 2016, China had the highest number of overseas student enrolments 121,300 students ( 31 percent) of all overseas tertiary students; Asia 286,750 (73.3 percent); Europe; 7,749 (19.8 percent); Middle East and 8,946 (2.3 percent) and Americas 12,316 (3.1 percent).

\footnotetext{
${ }^{1}$ https://internationaleducation.gov.au/research/International-Student-Data/Documents/MONTHLY SUMMARIES/2017/International student data December 2017 detailed summary.pdf
} 
A study conducted by Harman (2001) assesses the impact of NPM (New Public Management) on higher education sector in Australia and analyses reforms in the higher education sector since the mid-1980s. The study suggests ways in which NPM ideas have been transmitted to the higher education sector and translated into new policy frameworks and policy directions. Further, it assesses the extent to which the theoretical work of Ferlie et al. (1996) and Dunphy and Stace (1992) is useful in understanding the role of the Commonwealth Government in driving significant changes in national higher education policy and in the operation of individual universities.

The main research question of the current study is, 'what is the nature of the relationship between institutional websites and international student enrolments?' Based on this research question, the findings of this study will be used to compare the similarities and differences of university website content based on the selected two groups of universities: university websites with positive international student enrolments and university websites with negative international student enrolments. Moreover, to assess the website attributes, this study used the information, communication, transaction, relationship and technical merit (ICTRT) framework, which is a theoretical framework used to assess the website attributes using the five dimensions.

\section{Literature Review}

\subsection{Marketing strategies for international student recruitment}

The marketing strategies vary from country to country. As an example, Canadian universities do not involve many recruiting agencies. Even though web recruitment is frequently used in major countries, for higher education including Canada. It has negative effects on student enrolments as it depends on students seeking information through the university websites (Hossler, 2005). Conversely, Australian universities mainly depend on agents, approximately $46 \%$ of international students in Western Australia have been recruited via education agents (Wang, 2009) Moreover, the recruitment strategies for international students in the colleges by the Alberta, Canada include web publications, brochures, project partners, agents and alumni (Isa, Othman, \& Muhammad, 2016). However, other Canadian universities, use the web publication method(Howe, 2009). Critical success factors for international education marketing include the image of the institute and the market; organization of the courses and programs in a way that differentiates the product from other institutes; development of the resource stocks; strategic alliances; and forward integration with marketing channels (Brown \& Mazzarol, 2009). 
A study found that the postgraduate information materials provided by certain UK universities for Masters programs are an ineffective marketing tool (Blackwell, Bowes, Harvey, Hesketh, \& Knight, 2001). A study conducted on Australian universities by Gatfield, Barker, and Graham (1999) revealed a substantial discrepancy between student perceived needs and printed communication tools. However, in a more recent study conducted in Australia it was found that printed media and websites were the most influential communication tools in the three Asian markets of Malaysia, Singapore and Hong Kong (Gray, Fam, \& Llanes, 2003). Chinese students constitute Australia's largest market share when considering higher education (Gomes \& Murphy, 2003). Furthermore, Bodycott (2009) reveals that Chinese students and their parents mostly rely on home country exhibitions and fairs as an initial source of information because most parents expect the seminars and fairs to provide quick answers for their questions.

\subsection{Role of websites in international student recruitment}

Education industry e-learning continue to reduce the associated costs for resources and will also increase the accessibility of resources (Mandel, Hof, Foust, \& Muller, 2001). A study by Klassen (2002), identifies the lack of interaction and relationship building capabilities of the low ranking university websites as a major reason for their lower student enrolment. The institutes that target international students should enhance their international student recruitment process through improving their online customer service as most of the students rely on the internet when selecting a study destination (Gomes \& Murphy, 2003). University websites are the main source for learning more about higher education institutions. Therefore, the website is considered as an essential element in a successful marketing practice (Carnevale, 2005).

\subsection{Theoretical framework measuring the website effectiveness of the study}

From the communication perspective, every effective piece of communication has a clearly stated purpose that should be understood by both the creator and the audience (Li \& Wang, 2011). Company websites are crucial elements in attracting customers and are used as a marketing strategy, which is internet marketing that is different from the traditional marketing as it depends on the support of information technology Li and Wang (2011). Website evaluation is based on three criteria: evaluation by phase, evaluation by features and evaluation by features and effectiveness (Doolin, Burgess, \& Cooper, 2002; Law \& Hsu, 2005; Wang \& Russo, 2007). 
Based on this concept, Li and Wang (2011) propose a more concise framework, the ICTRT model to evaluate effectiveness of the websites. This model been tested only in websites related to the tourism and hospitality industries (Charoula, Eleonora-Ioulia, Fotini, \& Maro, 2014; Li \& Wang, 2011; Pai, Xia, \& Wang, 2014; Sun, Fong, Law, \& He, 2017; Yannacopoulos, 2014), and destination marketing organizations (Charoula et al., 2014; Manganari, Siomkos, Rigopoulou, \& Vrechopoulos, 2011; Park \& Gretzel, 2007) and to evaluate the websites of travel agencies (Rahnemai, Rezvani, Rahimpour, \& Jafari, 2015). Two main reasons are given for selecting this framework over the other models or frameworks. First, it reduces complexity of the evaluation process of the university websites because the analysis consists of a structure based on the ICTRT five dimensions. Second, this model is used to assess the website effectiveness of the destination marketing organizations, which is a similar process to international students selecting a study destination in a different country.

Figure 1:ICTRT Model to evaluate website effectiveness

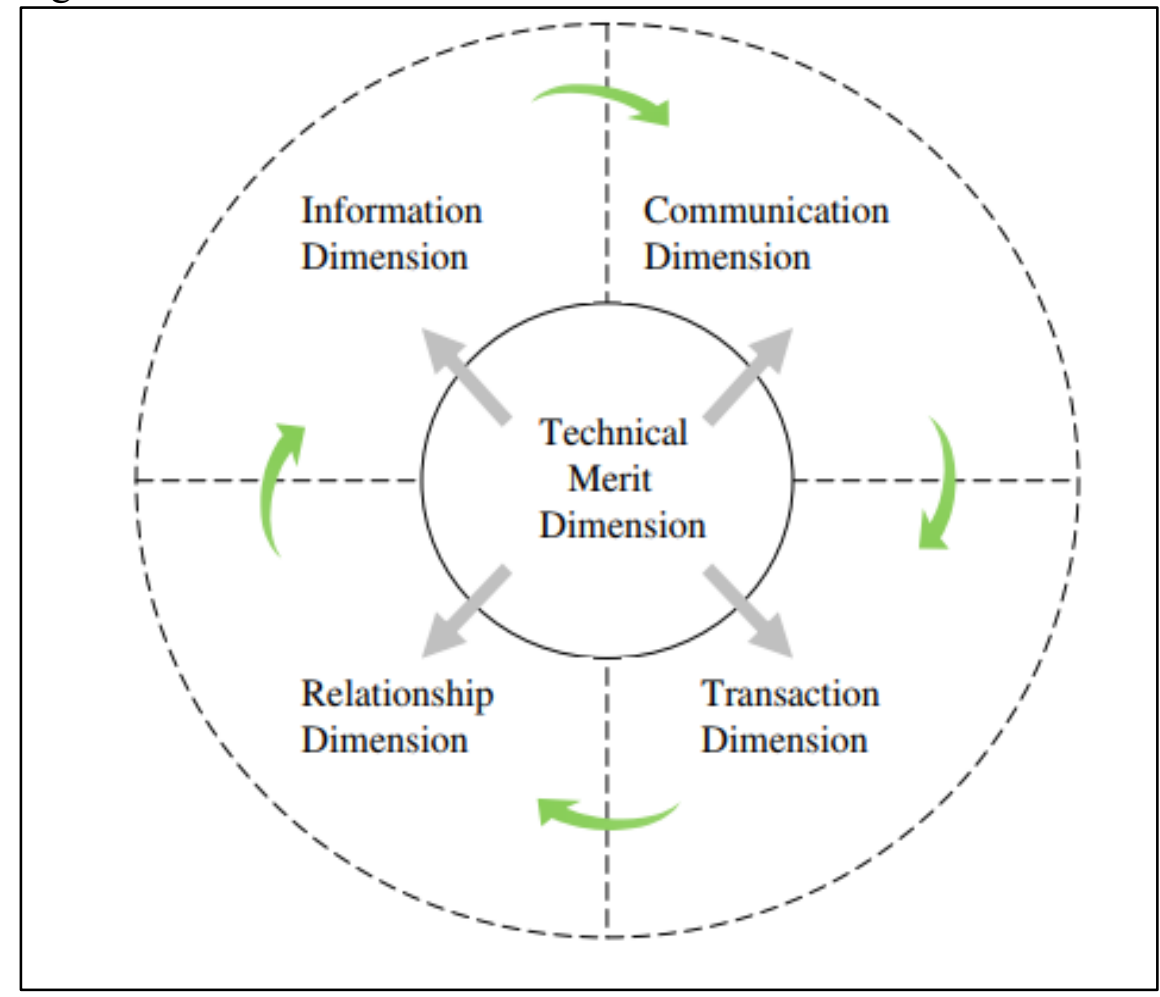

Source: Li and Wang (2011):Evaluating the effectiveness of destination marketing organisations' websites: evidence from China. International journal of tourism research, 12(5), 536-54 


\subsection{Website attributes measuring the website effectiveness based on the ICTRT framework}

The application of the ICTRT frameworks' five dimensions for this study is as below.

Table 1 comprises the criteria used in collecting the website attributes that apply to this study based on the ICTRT framework during the data collection process. For example, the information dimension represents information on resources and support services, financial advice, accommodation, travel and lifestyle. Moreover, the communication dimension allows students to communicate through enquiry facilities for online students, online glossary functions and multi language browsing facilities. None of the studies applied this model to evaluate tertiary education websites. Therefore, this is the first study to apply this framework for university websites. 
Table 1: Website attributes based on the ICTRT framework

\begin{tabular}{|c|c|}
\hline ICTRT framework & Website attributes \\
\hline Information dimension & $\begin{array}{l}\text { Home page of international students } \\
\text { Information divided according to different regions } \\
\text { Maps and directions } \\
\text { Support services and resources information } \\
\text { Sports and student societies information } \\
\text { Health and safety, medical and insurance information } \\
\text { Legal requirements } \\
\text { Accommodation information } \\
\text { Lifestyle information } \\
\text { Academic dates or calendar } \\
\text { Financial assistance/ living cost, travel, scholarships etc. } \\
\text { Study abroad and exchange information } \\
\text { Pre entry and pathway programs } \\
\text { Information from successful past students } \\
\text { Information about programs and courses } \\
\text { Policies and penalties } \\
\text { Travel guides or brochures } \\
\text { Telecommunication information }\end{array}$ \\
\hline Communication dimension & $\begin{array}{l}\text { Online facilities for lodging complaints or academic appeals } \\
\text { Search engine function } \\
\text { Online glossary function } \\
\text { Multi -language versions } \\
\text { Facility for online student enquires } \\
\text { Brochure request capabilities } \\
\text { Website feedback columns } \\
\text { Contact information (email, phone, mailing address, etc.) } \\
\text { FAQ's for international students }\end{array}$ \\
\hline Transaction dimension & $\begin{array}{l}\text { Online booking facilities for free airport pickup } \\
\text { Online accommodation booking } \\
\text { Employment database. } \\
\text { Online booking facilities of pre arrival information sessions } \\
\text { Accommodation search via university database and portals } \\
\text { Agent database }\end{array}$ \\
\hline Relationship dimension & $\begin{array}{l}\text { Self-credit and admissions assessment facility } \\
\text { Self-course fee calculator } \\
\text { Self-offer acceptance and defer } \\
\text { Self -enrolment facility } \\
\text { Customized or filtering options } \\
\text { Privacy policy }\end{array}$ \\
\hline Technical merit dimension & $\begin{array}{l}\text { Navigation } \\
\text { Relevant links (online budgeting tools, currency converter etc.) } \\
\text { Link workability } \\
\text { Webpage design and site map } \\
\text { Availability of videos } \\
\text { Links to social media (YouTube, blogs, etc.) }\end{array}$ \\
\hline
\end{tabular}

Source: The web links of the university $A, B, C, D, E$ and $F$ 


\section{Methodology}

The current study uses a multiple case study methodology due to two reasons. First, this study focuses on the website content of the six selected universities, which is the case scenario. Multiple case studies have analysed website content (Rahnemai et al., 2015; Sabaruddin, Abdullah, \& Jamal, 2012; Wang, 2009). Second, the current study explores the impact of institutional websites on recruiting international students in a detailed manner considering all the relevant website content. Creswell and Clark (2007) mentioned that case studies are considered as a technique in which the researcher explores a phenomenon in depth.

\subsection{Data Collection and sampling plan}

Primary data collection is via university websites and secondary data collection is via journals, books and annual reports. The study focuses on website effectiveness in recruiting international students by considering six selected university websites within a limited time. Therefore, this data collection method could lead to savings in time and cost. Stability and consistency is ensured by referring to the previous literature, which used similar methodologies and similar data collection sources. The selection of the six university websites is based on international student enrolment data of the higher education statistics database (uCube) ${ }^{2}$. The population of this study is the 43 universities in Australia. From the total of forty Australian universities, a sample of six Australian university websites has been selected considering the postgraduate and undergraduate international student enrolment percentage variance from 2011 to 2016. ( see Table A and Table B showing international postgraduate and undergraduate student enrolments and percentage variance over six years in the Appendices). Therefore, as shown in these tables, three university websites with positive international student enrolments percentage variance from 2011 to 2016 are University A, University B and University C. Similarly, the university websites with negative percentage variance are University D, University $\mathrm{E}$ and University F. The constant percentage variance is disregarded due to the unavailability. Please note that percentage variance from 2011 to 2016 in international student enrolments are considered, including enrolments for both undergraduate and postgraduate international students. Therefore, the basis for this university selection is only the percentage variance for international student enrolment and not any other factor, such as the universities' size, state, recognition or other factors. Table 2 provides a brief overview of the selected sample of the study.

\footnotetext{
${ }^{2}$ http://highereducationstatistics.education.gov.au/
} 
Table 2: Overview of the study sample

\begin{tabular}{|c|c|c|c|c|c|c|}
\hline $\begin{array}{l}\text { University } \\
\text { name }\end{array}$ & $\begin{array}{l}\text { Total } \\
\text { students }\end{array}$ & $\begin{array}{l}\text { Total } \\
\text { academic } \\
\text { staff }\end{array}$ & $\begin{array}{l}\text { Start } \\
\text { year }\end{array}$ & $\begin{array}{l}\text { The } \\
\text { University's } \\
\text { state }\end{array}$ & $\begin{array}{l}\text { Percentage change } \\
\text { of international } \\
\text { postgraduate } \\
\text { student enrolments } \\
\text { from } 2012 \text { to } 2016\end{array}$ & $\begin{array}{l}\text { Percentage change of } \\
\text { international } \\
\text { undergraduate } \\
\text { student enrolments } \\
\text { from } 2012 \text { to } 2016\end{array}$ \\
\hline University A & 46678 & 3360 & 1850 & $\begin{array}{l}\text { New South } \\
\text { Wales }\end{array}$ & $+116.14 \%$ & $+28.63 \%$ \\
\hline University B & 57433 & 3204 & 1958 & Victoria & $+93.92 \%$ & $+11.49 \%$ \\
\hline University $\mathrm{C}$ & 42182 & 3311 & 1853 & Victoria & $+99.68 \%$ & $+32.92 \%$ \\
\hline University D & 17388 & 1435 & 1856 & $\begin{array}{l}\text { South } \\
\text { Australia }\end{array}$ & $-12.44 \%$ & $-44.62 \%$ \\
\hline University $\mathrm{E}$ & 13545 & 524 & 1967 & Queensland & $-7.46 \%$ & $-61.62 \%$ \\
\hline University $\mathrm{F}$ & 31772 & 1882 & 1971 & Queensland & $-2.77 \%$ & $-21.46 \%$ \\
\hline
\end{tabular}

Note: + Percentage represents an average growth in student enrolments from 2012 to 2016.

Seven inclusion criteria and three exclusion criteria are used in selecting the study sample. Table 3 illustrates the inclusion and exclusion criteria of the study sample.

Table 3: Inclusion and exclusion criteria of the study sample

Inclusion criteria Exclusion criteria

\begin{tabular}{ll}
\hline Total international student enrolment for all the & International student enrolment for short term, \\
modes of attendance such as internal, external, & English language courses, or other pre-entry or \\
multi modal, on-line, fulltime and part-time & pathway programs.
\end{tabular}

from 2011 to 2016 .

International student enrolments only for

postgraduate and undergraduate programs.

A non-probability sampling plan of purposive sampling technique applies in this study. When considering the unit of analysis, the study focuses on the group level as it compares the positive and negative international student enrolments of the institutions (refer Figure 2).

Figure 2: Steps in sample selection decision making

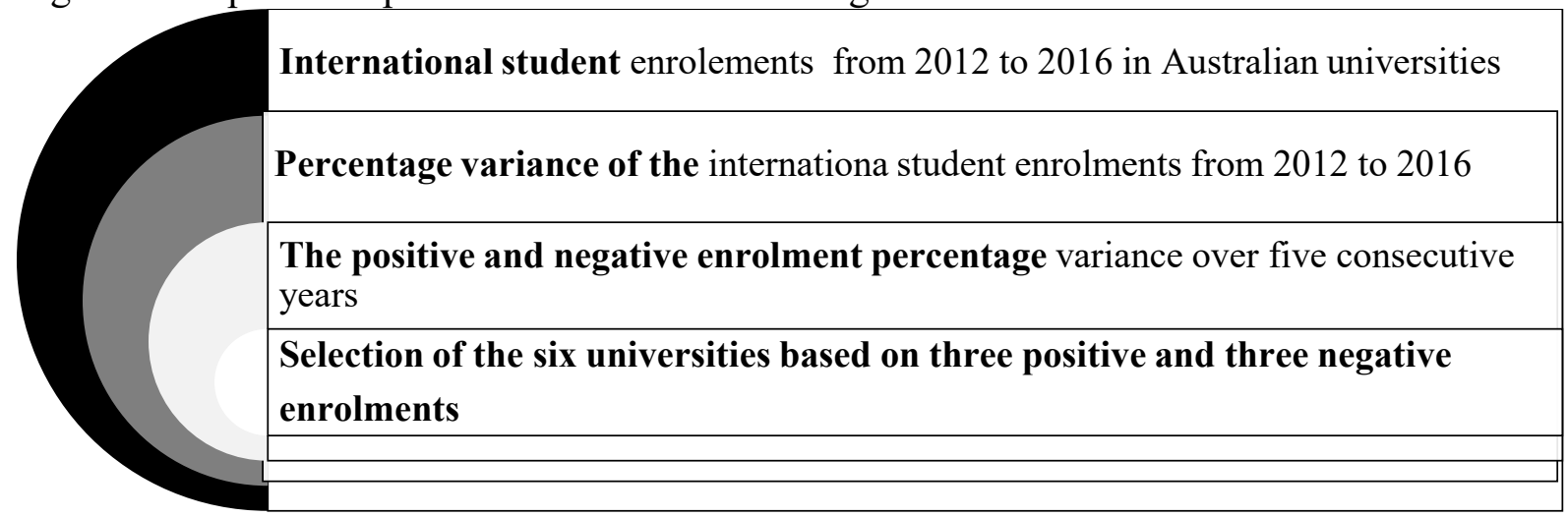

Note: Filtering variable under each step is highlighted in bold text. 


\subsection{Data Analysis}

The website content of the selected six universities will be analysed using thematic analysis (Creswell \& Clark, 2007; Tracy, 2012) through the qualitative data analysis software of Leximancer 4.5 (Smith \& Firth, 2011). The results will be based on the derived conceptual maps and themes. The analysis consists of two levels. In the level 1 analysis, the researcher will construct two conceptual maps using Leximancer. The first map will be constructed by entering the collected web content of the five dimensions of the selected three university websites with positive enrolments and the second map will be constructed using the same method for the selected three university websites with negative enrolments. Therefore, overall themes and concepts of the website content of universities with positive and negative international student enrolments will be analysed in detail using the illustrative narratives from the data set. Level 2 analysis consists of ten maps. Five maps represent the five dimensions of the ICTRT framework for university websites with positive international student enrolments and five maps for the university websites with negative international student enrolments.

\section{Results}

This section consists of the level 1 and level 2 analysis that addresses the main research question of, 'what is the nature of the relationship between institutional websites and student enrolments?' The level 1 analysis consists of an overall analysis of the themes of the website content of universities with positive and negative international student enrolments. The level 2 analysis consists of ten maps. Five maps represent the five dimensions of the ICTRT framework for university websites with positive international student enrolments and five maps represent the framework dimensions for the university websites with negative international student enrolments. 


\subsection{Level 1 analysis}

Comparison of the overall web content of the universities with positive international student enrolments

This section consists of an overall thematic analysis based on the ICTRT framework's five dimensions. The concept map with seven major themes and concepts based on the ICTRT framework application are shown in Figure 4.

Figure 4: Overall theme map of the university websites with positive international student enrolments

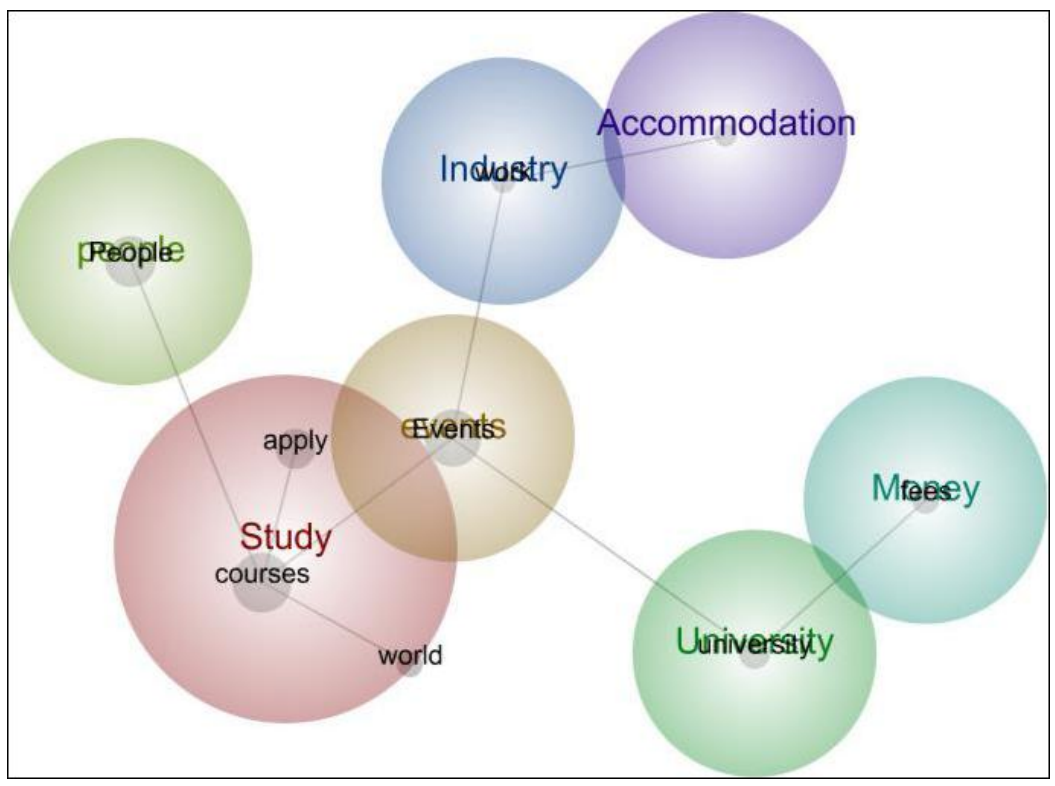

The dominant themes are "study", "people", "resources", "university", "money", "industry" and "accommodation". The nine concepts derived are "students", "course", "events", "apply", "university", "fees", "world", "work" and "accommodation". A truncated list of the themes with their frequency of occurrence in the dataset is available in Table 4 . The nine concepts within these themes and their count and relevance using the frequencies of occurrence in the respective webpages is available in Table 5. Count represents the number of occurrences in each concept while relevance denotes the most frequent concepts or proportionality of the concepts. For example, 'people' has a count of 273,988 and $100 \%$ relevance. 
Table 4: Synopsis of the analysis

\begin{tabular}{llllll}
\hline Themes & Frequency & & Concepts & Count & Relevance \\
\cline { 1 - 2 } \cline { 5 - 6 } Study & 308,036 & & People & 273,988 & $100 \%$ \\
People & 273,988 & & Courses & 266,985 & $97 \%$ \\
Events & 225,325 & & Events & 225,325 & $82 \%$ \\
University & 76,663 & & Apply & 85,316 & $31 \%$ \\
Money & 52,277 & & University & 76,663 & $28 \%$ \\
Industry & 27,628 & & Fees & 52,277 & $19 \%$ \\
Accommodatio & & & & & \\
$\mathrm{n}$ & 21,119 & & World & 29,401 & $11 \%$ \\
\cline { 5 - 6 } & & & Work & 27,628 & $10 \%$ \\
\cline { 5 - 6 } & & & Accommodation & 21,119 & $08 \%$ \\
\cline { 5 - 6 } & & & & &
\end{tabular}

The narrative illustrations of the major themes are presented in Table 6.

Table 6: Narrative illustrations of the major themes

\begin{tabular}{|c|c|}
\hline Theme & Narrative illustrations of the dataset \\
\hline study & $\begin{array}{l}\text { "Step 2: To plan your course use the resources on the "Get Started" website to } \\
\text { learn about your course's structure and requirements ...." }\end{array}$ \\
\hline people & $\begin{array}{l}\text { "Current students......" } \\
\text { "Study abroad and student exchange...." }\end{array}$ \\
\hline events & $\begin{array}{l}\text { "Career services...." } \\
\text { "Alumni benefits and awards..." } \\
\text { "During business hours contact the University counselling services....." }\end{array}$ \\
\hline university & $\begin{array}{l}\text { "Essential skills for life beyond university...." } \\
\text { "Departing the airport..." } \\
\text { "Travel times to campuses......." }\end{array}$ \\
\hline money & $\begin{array}{l}\text { "Finances, fees and cost of living in Australia ......." } \\
\text { "weekly rental costs in Australian dollars......" }\end{array}$ \\
\hline industry & $\begin{array}{l}\text { "Working in Australia..." } \\
\text { "Permission to work...." } \\
\text { "Work rights......." }\end{array}$ \\
\hline accommodation & $\begin{array}{l}\text { "Finalizing long-term accommodation..." } \\
\text { "On-campus and off campus accommodation...." }\end{array}$ \\
\hline
\end{tabular}

The analysis of the website content of universities with positive international student enrolments consists of several important findings. First, the websites of the universities with positive international student enrolments mainly focus on information on study programs implied by the major theme "study", which includes information on course units and subjects. Generally, this information is the primary concern of future students as they browse the university websites to find information on programs and courses. The second main theme is "people", which consists of staff (administrative personnel, academics) and students. It is vital to allow access to staff member through university websites as some students prefer to directly talk for more information. Therefore, as the second major important theme, "people" denotes human resource engagement within the university websites and narrative illustrations shows that the website mainly focuses on current and future students in providing this information. The "events" denote the third major 
theme that focuses more on resource availability. The next major theme of "university" informs international students about travel information for branch campuses and main campuses. This section is helpful for international students in finding branch campuses. The fifth theme "money" is another major factor for most international students as the selection of the university depends on the level of the students' funding. This section consists of details on scholarships, study loans, fees and deadlines.

Moreover, the next theme "industry" offers information on employment, experience and professional criteria. It is eventually employment that the education leads to. Therefore, the education focuses on future jobs, it needs the professional or academic practice. Competition for jobs is influenced by many factors, including the quality of qualifications and level of the training. Therefore, some university websites include an alumni section, which consists of the comments of past students who are working for globally recognized companies such as Microsoft, Google and IBM. These comments help prospective students to select an appropriate course.

The theme "accommodation" is another requirement for students who are new to the country. The websites provide information and facilitates students in selecting an appropriate location. Some universities have an accommodation database and online booking facilities. Finally, the two themes "money" and "accommodation" intersect, which means the information about the two themes are interconnected. The above analysis shows that these two themes inform the international students about the accommodation information by linking that with the part time job opportunities which will support them to cover the cost of living (accommodation). Therefore, it is evident that the university websites with positive international student enrolments provides direct and most useful information to the international students, focusing on their exact needs such as money, accommodation, course information and employment. 
The narrative illustrations of the concepts of the major themes are presented in Table 7.

Table 7: Narrative illustrations of the concepts

\begin{tabular}{|c|c|c|}
\hline Theme & Concepts & Narrative illustrations of the dataset \\
\hline study & $\begin{array}{l}\text { courses } \\
\text { apply } \\
\text { world }\end{array}$ & $\begin{array}{l}\text { "how to get help if needed in planning your course...." } \\
\text { "Apply now-use the resources on the "Get Started" website to learn about } \\
\text { your course's structure and requirements...... } \\
\text { "The university websites provide more information on their world rank....... }\end{array}$ \\
\hline people & people & $\begin{array}{l}\text { "Visas for family members.... Family members may be included in your } \\
\text { application ......" }\end{array}$ \\
\hline events & events & $\begin{array}{l}\text { "I recommend to not pack too much as you are going to find a lot of nice } \\
\text { things that you want to bring back home. However, don't forget that winter in } \\
{[\text { [CITY] is quite cold and rainy, so bring warm clothes......" }}\end{array}$ \\
\hline university & apply & $\begin{array}{l}\text { "Direction to [SUBURB] campus......" } \\
\text { "Authorized Officers travel on the trains, trams and buses often check if } \\
\text { commuters have valid tickets......". }\end{array}$ \\
\hline money & fees & $\begin{array}{l}\text { "Finances, fees and cost of living in Australia ......." } \\
\text { "weekly rental costs in Australian dollars......" }\end{array}$ \\
\hline industry & work & $\begin{array}{l}\text { "During the semester, you must not exceed the number of hours of work } \\
\text { allowed ......", } \\
\text { "Working in Australia....." }\end{array}$ \\
\hline accommodation & - & - \\
\hline
\end{tabular}

The theme "study" was developed from three frequently appearing concepts, "apply", "courses" and "world". These concepts show a close relationship with the "study" theme, and most of the concepts had a higher frequency of occurrence with this theme. Figure 5 further explores the concept "courses", which is more closely related to the theme "study". When further exploring this concept, narrative illustrations support the major findings of the theme "study", which includes information on course units and subjects.

The major concept of the theme "people" denotes that the website provides information regarding the students, their families and their family visa procedures. In addition to the major findings of the theme events, the concept illustrations show information on lifestyles in the respective cities. Similarly, in addition to the major findings of the theme "university", concept illustrations provide information for international students about maps and directions for branch campuses and information about travel. The concept illustrative narrations of the theme "money" have one major concept, "fees". Further investigation of this concept shows that these websites focus on information about both tuition fees and living expenses. The concept illustrative narrations of the theme "industry", which is "work" inform international students about the job opportunities that will support them to pay for or manage their living costs (accommodation). 


\section{Comparison of the overall web content of the universities with negative international student enrolments}

This section consists of an overall thematic analysis based on the ICTRT framework's five dimensions, which are information, communication, transaction, relationship and technical merits. The seven major themes and concepts based on the ICTRT framework application, which were derived from the overall concept maps of university websites with negative international student enrolments are shown in Figure 5.

Figure 5: Overall theme map of the university websites with negative international student enrolments

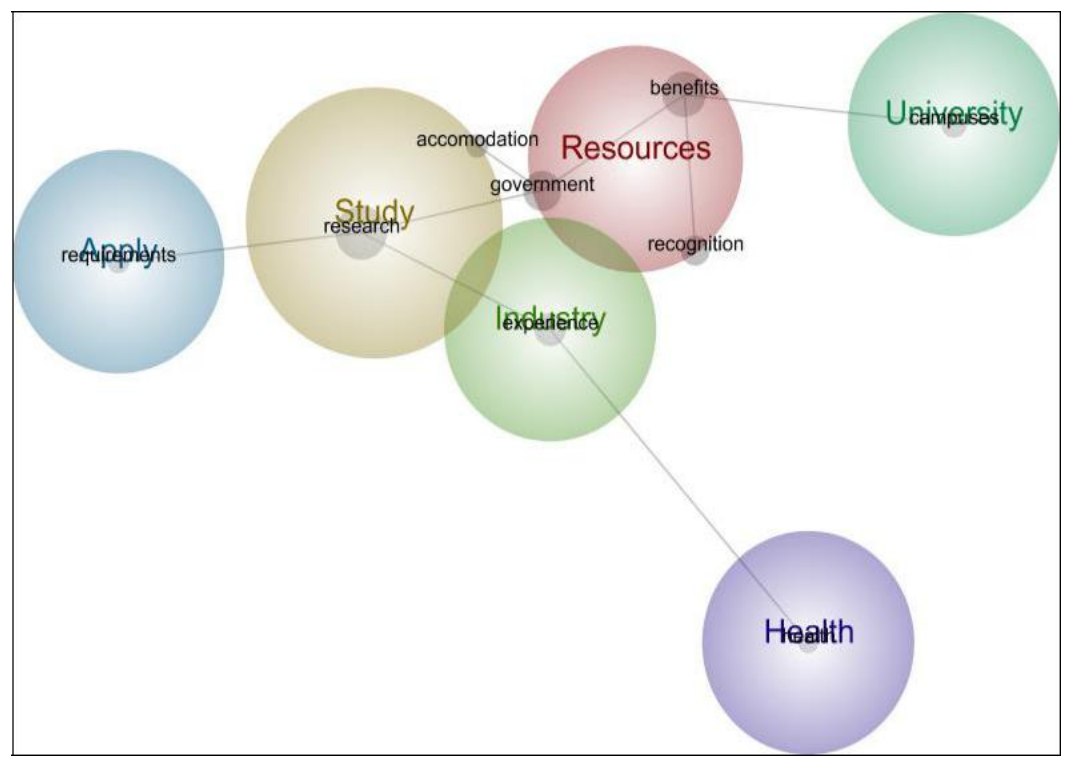

The dominant themes are "study", "resources", "industry", "university", "apply" and "health". The nine concepts derived are "research", "benefits", "government", "experience", "campuses", "quality", "requirements", "health" and "accommodation". A truncated list of the themes with the frequency is in Table 8. The nine concepts within these themes, their count and relevance are shown in Table 9. The name-like and word-like concepts have been ranked using the frequencies of occurrence in the respective webpages. Count represents the number of occurrences in each concept while relevance denotes the most frequent concepts or proportionality of the concepts. For example, 'research' has a count of 11,801 and $100 \%$ relevance. 
Table 8: Synopsis of the analysis

\begin{tabular}{ll}
\hline Themes & Frequency \\
\hline Study & 11,910 \\
Resources & 9,076 \\
Industry & 2,623 \\
University & 2,223 \\
Apply & 1,404 \\
Health & 777 \\
\hline
\end{tabular}

Table 9: List of the nine name or word like concepts

\begin{tabular}{lll}
\hline Themes & Count & Relevance \\
\hline Research & 11,801 & $100 \%$ \\
Benefits & 5849 & $50 \%$ \\
Government & 3070 & $26 \%$ \\
Experience & 2623 & $22 \%$ \\
Campuses & 2223 & $19 \%$ \\
Quality & 2021 & $17 \%$ \\
Requirements & 1404 & $12 \%$ \\
Health & 777 & $07 \%$ \\
Accommodatio & & \\
$\mathrm{n}$ & 508 & $04 \%$ \\
\hline
\end{tabular}

The narrative illustrations of the major themes are presented in Table 10.

Table 10: Narrative illustrations of the major themes

\begin{tabular}{|c|c|}
\hline Theme & Narrative illustrations of the dataset \\
\hline study & $\begin{array}{l}\text { "Complete one or two trimesters of study in Australia and earn credit towards your home } \\
\text { degree......." }\end{array}$ \\
\hline resources & $\begin{array}{l}\text { "Our Advisors provide advice on how to navigate a wide range of issues ..." } \\
\text { "Access Plan.... which give you access to a range of additional supports such as } \\
\text { alternative print, lecture transcription ......" }\end{array}$ \\
\hline industry & $\begin{array}{l}\text { "Mentoring is a big help. Keeping in touch with the bosses or colleagues who have made an } \\
\text { impact on you ......" }\end{array}$ \\
\hline university & $\begin{array}{l}\text { "Proposals for New Academic Programs may be initiated by Faculties, other } \\
\text { organizational units including campuses or Marketing and Student Attraction ...." }\end{array}$ \\
\hline apply & $\begin{array}{l}\text { "Failure to comply with this policy or policy instrument may be considered as misconduct } \\
\text { and the provisions of the relevant policy or procedure applied...." }\end{array}$ \\
\hline health & $\begin{array}{l}\text { "Hospitals and health care facilities....", and "I was a high school teacher for four years } \\
\text { and then, just by luck, I worked in an adolescent mental health unit as a teacher. I really } \\
\text { enjoyed supporting the wellbeing of young people, and so I decided to undertake a Masters } \\
\text { of Education with a major in Guidance and Counselling........." }\end{array}$ \\
\hline
\end{tabular}


The analysis of the website content of universities with negative international student enrolments consists of several important findings. The main focus is on studies (courses) similar to those universities with positive enrolments. Three major themes are in common: "study", "industry" and "university." First, the theme "study" revealed that the website information of the universities with negative international student enrolments provides more focus on postgraduate and higher degrees by research. There was a mismatch in the information provided with the topics in the two concepts of "accommodation" and "government."

The second major theme, "resources", focuses on the facilities offered and access given to international students, with some focus on government support and partnerships. The third major theme is "industry", which is common to both types of university websites. This theme includes information on the future career perspectives of students and comments from past successful students. "University" is the next theme, which consists of information on faculties and personnel and lacks major details such as location maps and travel information. Websites provides information on resources rather than general information about each campus. Moreover, the next theme "apply" consists of information on policies and procedures. It provides more focus on university admission policy for higher degrees by research and support provided by the government. Finally, the theme "health" focuses on the information about safety, medical and insurance facilities with a special focus on the mental health and wellbeing of the students. The narrative illustrations of the concepts of the major themes are presented in Table 11.

Table 11: Narrative illustrations of concepts

\begin{tabular}{|l|l|l|}
\hline Theme & Concepts & Narrative illustrations of the dataset \\
\hline study & research & $\begin{array}{l}\text { "Explore-postgraduate coursework and higher degrees by research......" } \\
\text { "Our teaching staff are internationally recognized for their excellence in } \\
\text { research and play a hands-on role in guiding students through.... }\end{array}$ \\
\hline resources & $\begin{array}{l}\text { benefits } \\
\text { government } \\
\text { recognition }\end{array}$ & $\begin{array}{l}\text { "Find out about financing study through your home country's loan program, } \\
\text { sponsored student support and scholarships". } \\
\text { "By partnering with government, industry, schools and the wider community } \\
\text { lasting difference opening a world of opportunity for all...." }\end{array}$ \\
\hline industry & experience & $\begin{array}{l}\text { "After working in IT within a multi-national company, I wanted to develop my } \\
\text { skills beyond my background of electronics and instrumentation....." }\end{array}$ \\
\hline university & campuses & $\begin{array}{l}\text { "Investigate employment opportunities available across our five } \\
\text { campuses......" }\end{array}$ \\
\hline health & requirements & $\begin{array}{l}\text { "Students seeking entry to programs at the university must satisfy the General } \\
\text { Admission Principles outlined in Section 4.1 ......." }\end{array}$ \\
\hline health & $\begin{array}{l}\text { "Australia's stable political system, low crime rate, well-maintained roads and } \\
\text { high standard of health care make it a safe and pleasant country to study and } \\
\text { explore...... } \\
\text { "I want my son to grow up within a community where he can talk about his } \\
\text { mental health, the same way he can talk about having a cold.........". }\end{array}$ \\
\hline
\end{tabular}


The theme "study" was developed out of the frequently appearing concept of "research". University websites with negative international student enrolments encourage students to browse the program information and to find about the exemptions with more focus on postgraduate degrees. Figure 6 further explores the concept "research". which is more closely related to the theme "study". When further exploring this concept, narrative illustrations support the major findings of the theme "study", that includes information on postgraduate and higher degrees by research.

Three concepts for the second theme include "benefits", "government" and "recognition". Further analysis of these concepts provides information on loans and financial support but there is a mismatch with the topic and the content. The narrative illustrations of University F's database on the second most closely associated concept of "government" illustrations show information on government support and partnerships. University database explains that the theme "resources" consists of information on supporting services and government support.

The concept illustrative narrations of the theme "industry" indicate that the websites of these universities show the quality standards of the courses via the comments of past successful students. Further analysis of the concept illustrative narrations of the "university" theme provides information on facilities of the campus and not about travelling details (maps) or branch campuses. Moreover, concept illustrative narrations of the theme "apply" contain one major concept "requirements", which offers information on university admission policies for 'Higher Degrees by Research' and support provided by the government. Finally, concept illustrative narrations of the "health" theme focus on the information about health, safety, medical facilities and insurance, with a special focus on the mental health and wellbeing of students.

\subsection{Level 2 analysis - Results based on the ICTRT framework application}

This section presents the results of level 2 analysis, which involves the application of the ICTRT framework's five dimensions for the university websites with either positive and negative international student enrolments. This section consists of a thematic analysis using major themes and concept maps. The concept map in Figure 6 illustrates the dominant themes of the "information dimension" of the universities with positive international student enrolments. 
Figure 6: "information" dimension of the university websites with positive student enrolments

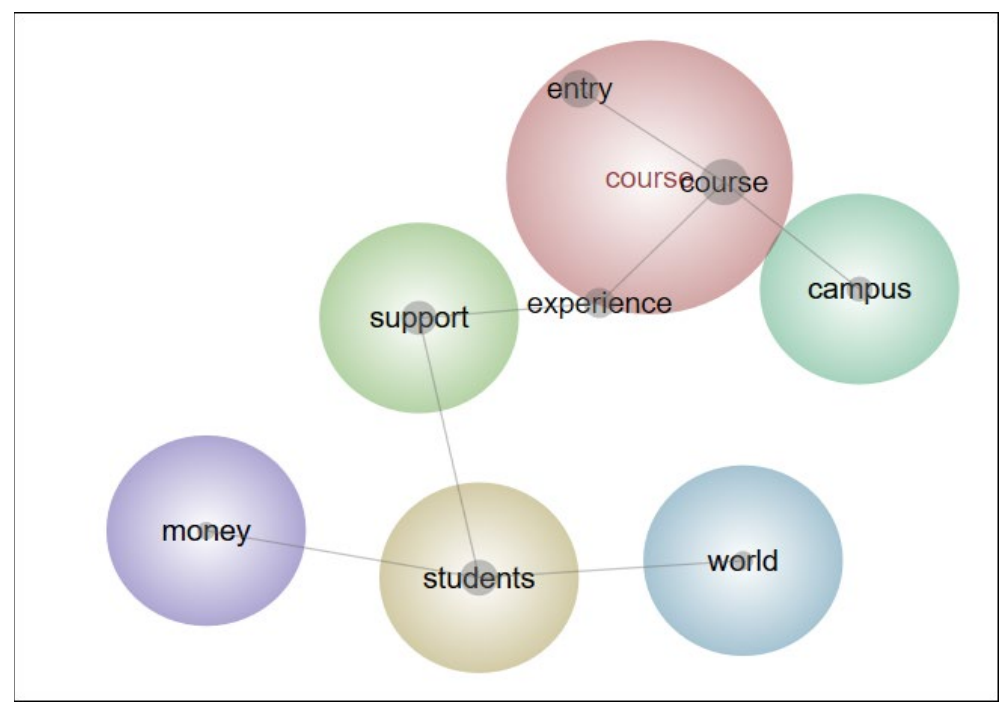

The narrative illustrations of the major themes from the database is presented in Table 12 . Table 12: Narrative illustrations of themes

\begin{tabular}{|c|c|}
\hline Theme & Narrative illustrations of the dataset \\
\hline course & $\begin{array}{l}\text { "Plan your Course... use the resources on the 'Get Started' website to learn } \\
\text { about your course structure and requirements......" }\end{array}$ \\
\hline students & $\begin{array}{l}\text { "We are proud to attract the best and brightest students around the world, } \\
\text { and future students...." }\end{array}$ \\
\hline support & $\begin{array}{l}\text { "Academic support......," } \\
\text { "Career services .....", } \\
\text { "During business hours contact the University counselling services......" }\end{array}$ \\
\hline campus & $\begin{array}{l}\text { "Travel times to campuses......" } \\
\text { "Shopping for food and other items near campus......" }\end{array}$ \\
\hline world & "As one of Australia's leading universities-ranked in the world's top $100 \ldots . . . "$ \\
\hline money & "Fees, scholarships and financial support....... \\
\hline
\end{tabular}

When analyzing the most dominant theme which is "course", university websites provide information on programs such as cost, duration and course content. The second major theme "students" consists of information on future students. The third dominant theme "support" consists of information about resources. The next theme "campus" provides information on travel, maps and directions to branch campuses. The final two least influential themes "world" and "money" show the world ranking information and financial information (scholarships, bank loans) respectively. 
The concept map in Figure 7 illustrates the dominant themes on the "information dimension" of the universities with negative international student enrolments.

Figure 7: "information" dimension of the university websites with negative student enrolments

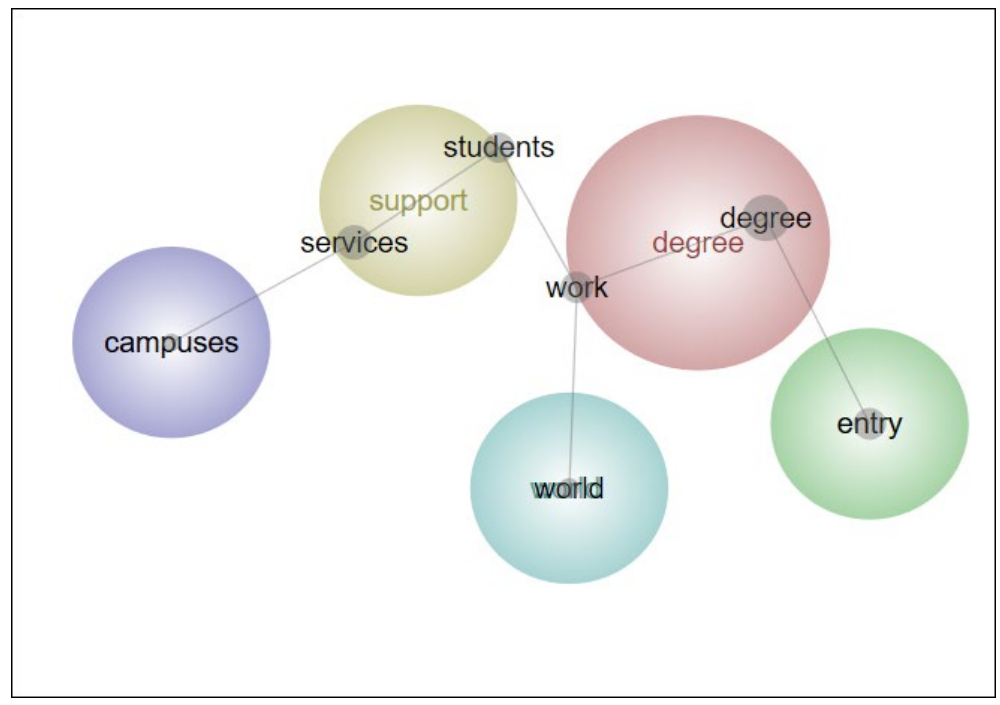

The narrative illustrations of the major themes from the database is presented in Table 13 .

Table 13: Narrative illustrations of the themes

\begin{tabular}{|l|l|}
\hline Theme & Narrative illustrations of the dataset \\
\hline degree & $\begin{array}{l}\text { "Onwards and upwards a postgraduate degree is the perfect tool to up-skill, } \\
\text { re-skill and move your career forward... }\end{array}$ \\
\hline support & $\begin{array}{l}\text { "Unlock the possibilities and access our state-of-the-art television, sound } \\
\text { and editing studios..." }\end{array}$ \\
\hline entry & $\begin{array}{l}\text { "These are programs normally offered under the heading of Pathways to } \\
\text { University and include Tertiary Preparation, Foundation Diplomas...... } \\
\text { "Applicants are required to submit their application using the nominated } \\
\text { system by the program closing dates as determined by the University....." }\end{array}$ \\
\hline world & $\begin{array}{l}\text { "UNIVERSITY] is in the Top [NUMBER] universities in the world under } \\
\text { [NUMBER] years old"..... }\end{array}$ \\
\hline campus & "Living type across all [NUMBER] campuses......" \\
\hline
\end{tabular}

Based on Figure 7, the themes "support", "campus" and "world" are common for universities with both negative and positive international student enrolments. These three common themes have different priority levels. For example, the theme "support" is the second major theme for universities with negative international student enrolments, while the theme "support" is the third major theme for universities with positive international student enrolments. 
When further analyzing the first theme, "degree", it is evident that websites provide more focus on postgraduate degrees and higher degrees by research. The second major theme, "support", denotes the availability of updated technology. The third major theme "entry" consists of information on admission and pathway programs. Finally, the two themes that are common and least significant for those universities are; "world" and "campus." The theme "world" represents information about the quality standards and university world ranking. The theme "campus" provides information on branch campuses.

The concept map presented in Figure 8 illustrates the dominant themes on the "communication dimension" of the universities with positive international student enrolments.

Figure 8: "communication" dimension of the university websites with positive student enrolments

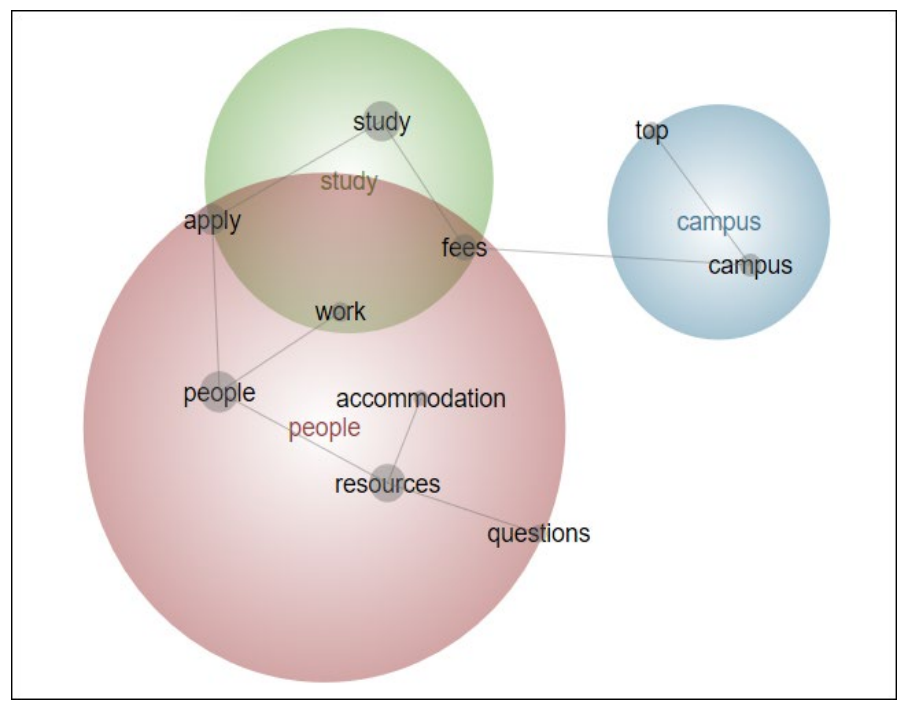

The narrative illustrations of the major themes from the database is presented in Table 14 . Table 14: Narrative illustrations of the themes

\begin{tabular}{|l|l|}
\hline Theme & Narrative illustrations of the dataset \\
\hline people & "Contact our staff members ....., "FAQs....., "View our brochures......." \\
\hline study & $\begin{array}{l}\text { "We have a range of pathway programs ......" } \\
\text { "The University provides a guarantee that the fee will not increase by more } \\
\text { than } 7 \text { per cent a year ........" }\end{array}$ \\
\hline campus & $\begin{array}{l}\text { "Our world university rankings......" } \\
\text { "Getting to }[N A M E] \text { campus from }[C I T Y] \ldots . . . .\end{array}$ \\
\hline
\end{tabular}


Figure 8 presents "people" as the major theme. This theme shows that universities with positive international student enrolments are more people-oriented and do not rely on the online communication aspect. The website directs international students to the contact details of the relevant staff members who will attend to their enquires. The second theme "study" provides information on pathway programs and fees. The next theme is "campuses" that consist information of the university ranking and branch campuses.

This concept map presented in Figure 9 illustrates the dominant themes of the "communication dimension" of the universities with negative international student enrolments.

Figure 9: "communication" dimension of the university websites with negative student enrolments

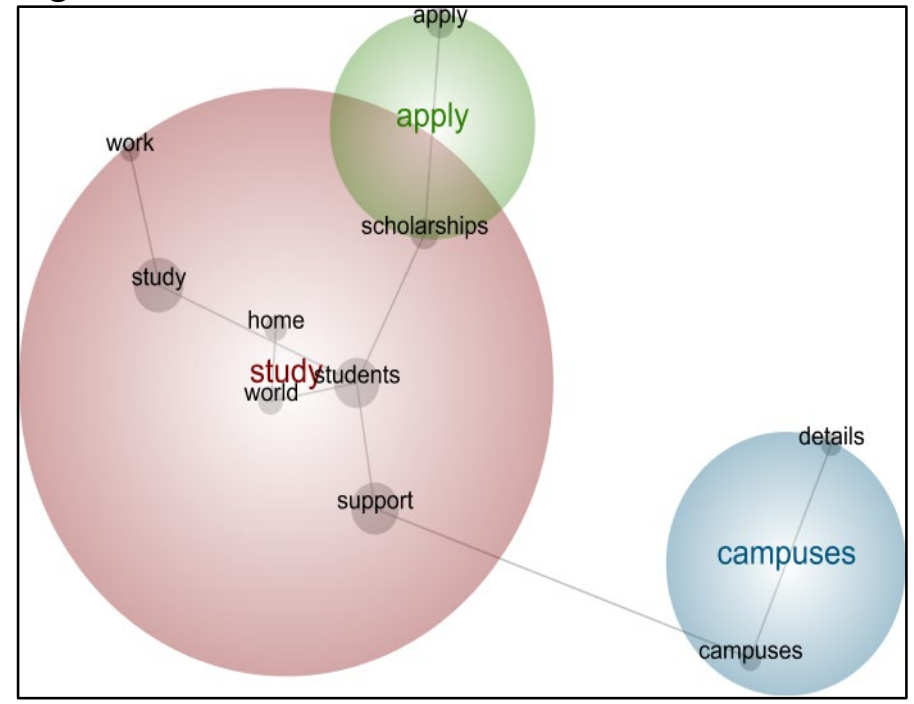

The narrative illustrations of the major themes from the database is presented in Table 15 . Table 15: Narrative illustrations of the themes

\begin{tabular}{|l|l|}
\hline Theme & Narrative illustrations of the dataset \\
\hline study & $\begin{array}{l}\text { "Collaborative research opportunities at [NAME] open doors to greater } \\
\text { innovation and discovery for higher degree researchers" } \\
\text { "Find out about financing study through loan program, sponsored student } \\
\text { support and scholarships " }\end{array}$ \\
\hline apply & "How do I apply for a scholarship/bursary...?" \\
\hline campus & "Find your way around our campuses with detailed building and parking \\
\hline
\end{tabular}


The themes "campus" and "study" are common for both universities with negative and positive international student enrolments. Figure 11 presents "study" as the major theme. This theme shows that universities with negative international student enrolments communicate about postgraduate degrees and monetary support. The second major theme, "apply", focuses only on the scholarship application process. The least influential theme "campuses" consists of information about maps, travel and directions to branch campuses. The concept map presented in Figure 10 illustrates the dominant themes of the "transaction dimension" of the universities with positive international student enrolments.

Figure 10: "transaction" dimension of the university websites with positive student enrolments



The narrative illustrations of the major themes from the database is presented in Table 16.

Table 16: Narrative illustrations of the themes

\begin{tabular}{|l|l|}
\hline Theme & Narrative illustrations of the dataset \\
\hline study & $\begin{array}{l}\text { "You can apply all year round for on- campus accommodation at [NAME] } \\
\text { University, apply for airport pickup......" } \\
\text { "please let us know when booking your online appointment and provide your } \\
\text { contact details........." }\end{array}$ \\
\hline people & $\begin{array}{l}\text { "Please choose a faculty or university staff member, Email invitation... } \\
\text { "Our staff can contact you via Skype, landline or mobile... }\end{array}$ \\
\hline money & "pay your fees web page" \\
\hline
\end{tabular}

Based on Figure 10, the major theme "study" illustrates transaction space in the university website regarding studies (exam booking), accommodation bookings, free airport pickup and online booking facilities of pre arrival information sessions. The second theme "people" illustrates the transaction possibilities provided within the websites with the assistance of staff members. The third theme 
"money" mentions the monetary transactions facilitated by the university websites.

The concept map presented in Figure 11 illustrates the dominant themes on the "transaction dimension" of the universities with negative international student enrolments.

Figure 11: "transaction" dimension of the university websites with negative student enrolments

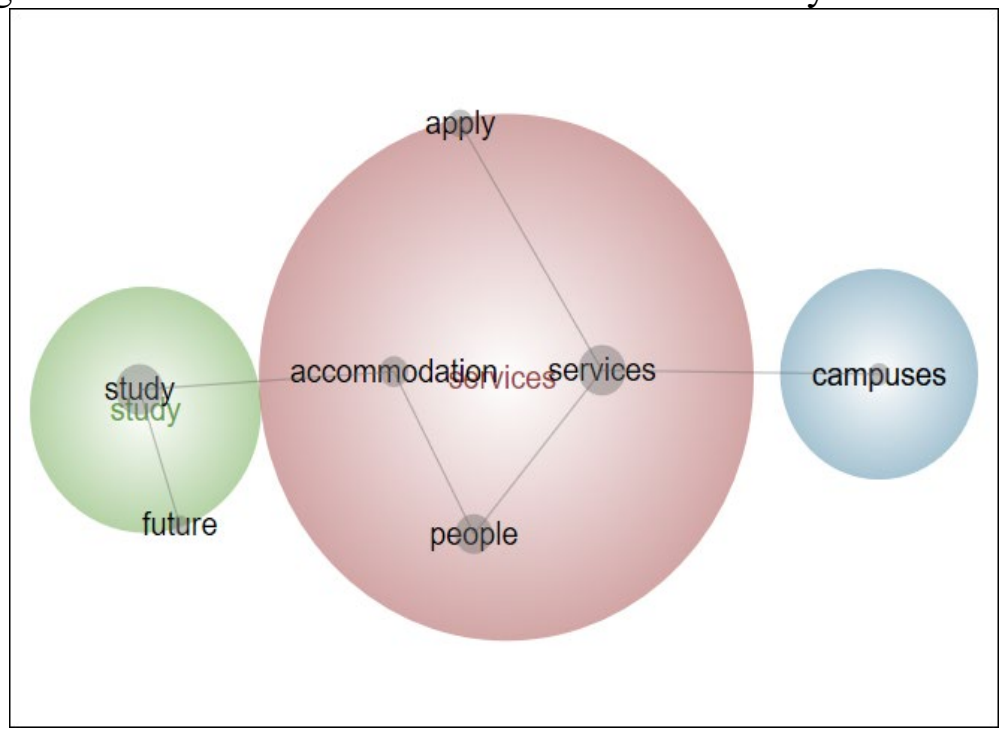

The narrative illustrations of the major themes from the database is presented in Table 17.

Table 17: Narrative illustrations of the themes

\begin{tabular}{|l|l|}
\hline Theme & Narrative illustrations of the dataset \\
\hline services & "Accommodation -Book now......." \\
& "University services including airport pick-up........." \\
\hline study & "Book now-On Open Day...." \\
\hline campuses & "Our campuses and facilities...." \\
\hline
\end{tabular}

The major theme "services" illustrates transaction possibilities in the university website such as university accommodation bookings and free airport pickup. The theme "study" mentions the transaction possibilities within the university website such as pre-arrival information booking sessions and so on. Finally, the theme "campuses" demonstrates the general transaction facilities offered by branch campuses, such as advice on resources and facilities available at the branch campuses. The concept map presented in Figure 12 illustrates the dominant themes of the "relationship dimension" of the universities with positive international student enrolments. 
Figure 12: "relationship" dimension of the university websites with positive student enrolments

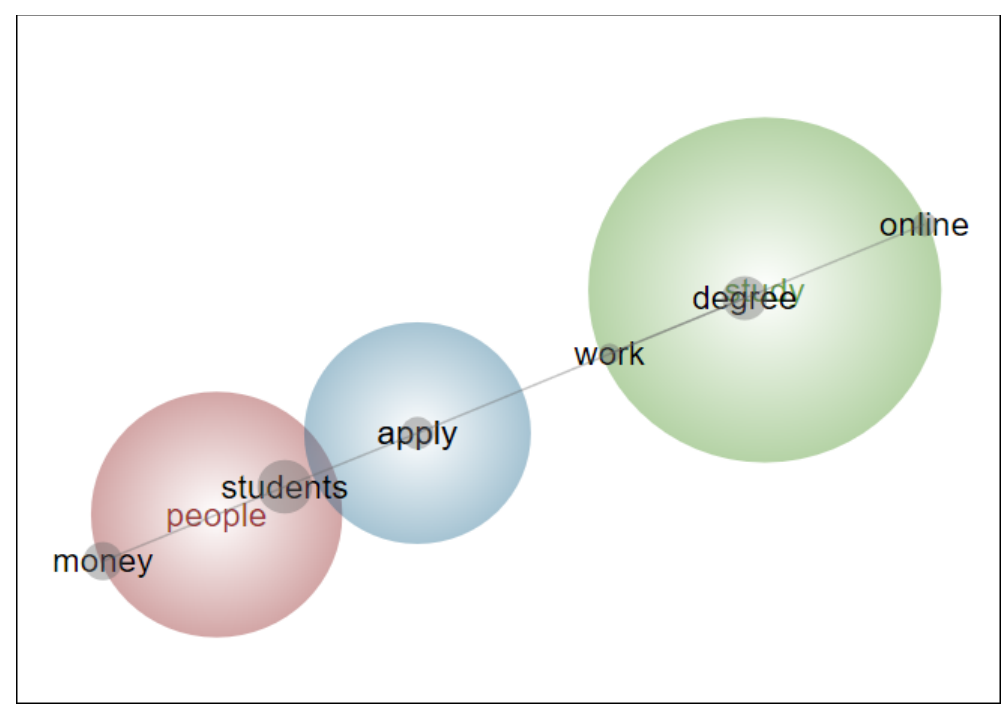

The narrative illustrations of the major themes from the database is presented in Table 18.

Table 18: Narrative illustrations of the themes

\begin{tabular}{|c|c|}
\hline Theme & Narrative illustrations of the dataset \\
\hline people & $\begin{array}{l}\text { "This calculator gives you an indicative total cost of study ....." } \\
\text { "Find a course and Find a scholarship....." }\end{array}$ \\
\hline study & $\begin{array}{l}\text { "[NAME] Student. During the enrolment process you will select units of study } \\
\text { (subjects), confirm your financial liability, upload a photo for your student } \\
\text { card .......", } \\
\text { "You can use the credit search online .........." }\end{array}$ \\
\hline apply & "Apply for an off-campus course \\
\hline
\end{tabular}

Based on Figure 12, the major theme "people", denotes the tools available in the university website such as self-course fee calculator, personalized search options and filtering options. The second theme "study" denotes relationship dimensions such as self-enrolment facilities, self-credit and admission assessment facilities. The final theme "apply" refers to the relationships maintained using the websites for the admission process.

The concept map presented in Figure 13 illustrates the dominant themes of the "relationship dimension" of the universities with negative international student enrolments. 
Figure 13: "relationship" dimension of the university websites with negative student enrolments

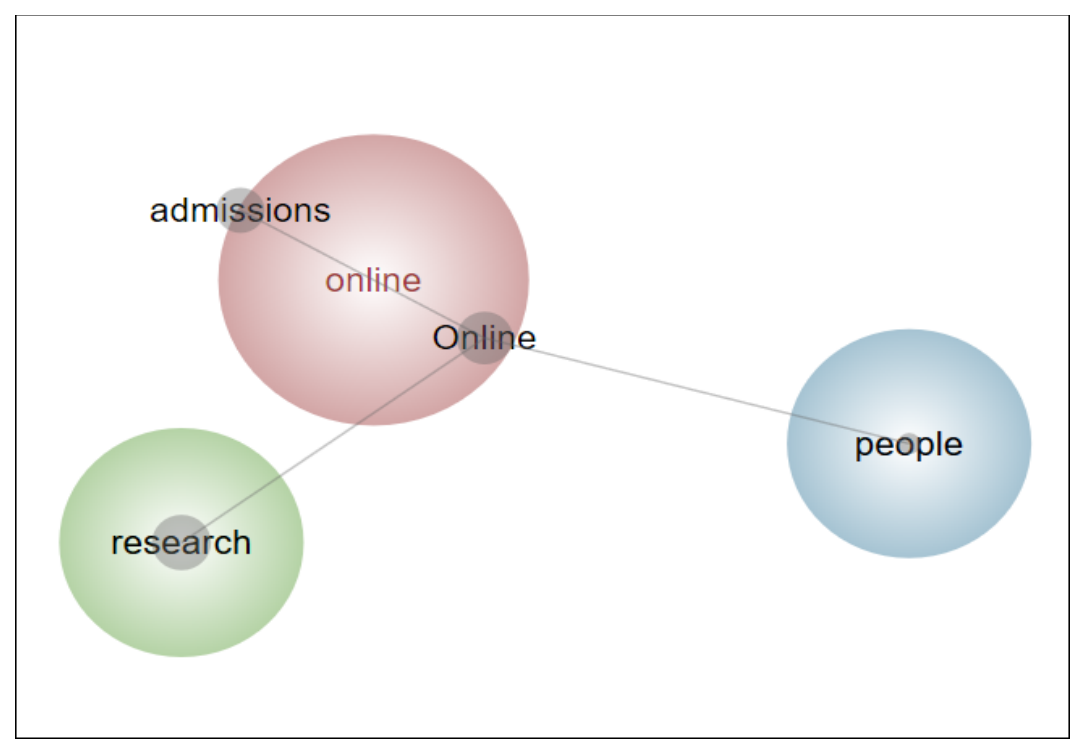

The narrative illustrations of the major themes from the database are presented in Table 19. Table 19: Narrative illustrations of the themes

\begin{tabular}{|c|c|}
\hline Theme & Narrative illustrations of the dataset \\
\hline research & $\begin{array}{l}\text { Research services-we offer hundreds of study options across a wide range of } \\
\text { areas... " }\end{array}$ \\
\hline online & $\begin{array}{l}\text { "Study online -Online learning, distance learning, off-campus and external } \\
\text { study modes ...." } \\
\text { online admission ...., please apply online "" }\end{array}$ \\
\hline people & $\begin{array}{l}\text { "[NAME] is collecting the personal information on this form for sl } \\
\text { students and prospective students and for marketing purposes...." }\end{array}$ \\
\hline
\end{tabular}

Based on Figure 13, the major theme "research" denotes the relationship dimension of personalized or filtering options to search for the courses. The second main theme "online" mentioned two major aspects of distance learning options and the online application process. The least significant theme is "people", which denotes the engagement of staff members in the relationship dimension.

The concept map presented in Figure 14 illustrates the dominant themes of the "technical dimension" of the universities with positive international student enrolments. 
Figure 14: "technical merits" dimension of the university websites with positive student enrolments

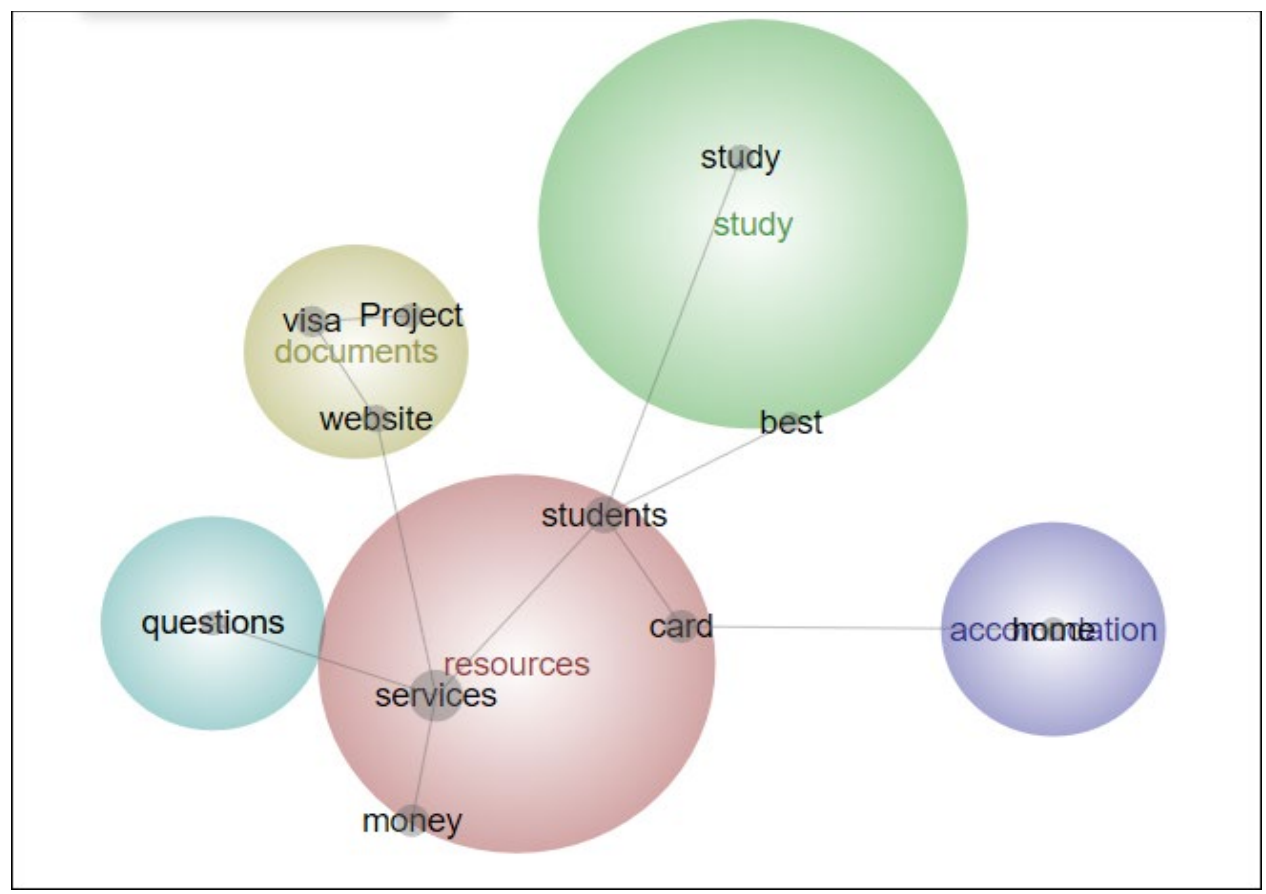

The narrative illustrations of the major themes from the database is presented in Table 20.

Table 20: Narrative illustrations of the themes

\begin{tabular}{|l|l|}
\hline Theme & Narrative illustrations of the dataset \\
\hline resources & "This calculator is designed to help you...." and "currency converter." \\
\hline documents & $\begin{array}{l}\text { "Please visit- www.homeaffairs.gov.au, Please follow us on Facebook Page } \\
\text { [NAME] ...." }\end{array}$ \\
\hline study & "Click on these videos on case studies and student stories....." \\
\hline accommodation & "Please visit www.visit (city).com" \\
\hline questions & "This page contains FAQs'........" \\
\hline
\end{tabular}

Based on Figure 14, the major theme "resources" illustrates website facilities such as online budgeting tools and currency converter tools. The second major theme "documents" shows the availability of information on insurance, visas and food, with external links to other websites and social media. The third theme "study" consists of links and videos that provide information on experiences of past students. The theme "accommodation" provides information of the lifestyle in the city via external links. Finally, the theme "questions" provides links for an FAQ section.

The concept map presented in Figure 15 illustrates the dominant themes on the "technical dimension" 
of the universities with negative international student enrolments.

Figure 15: "technical merits" dimension of the university websites with negative student enrolments

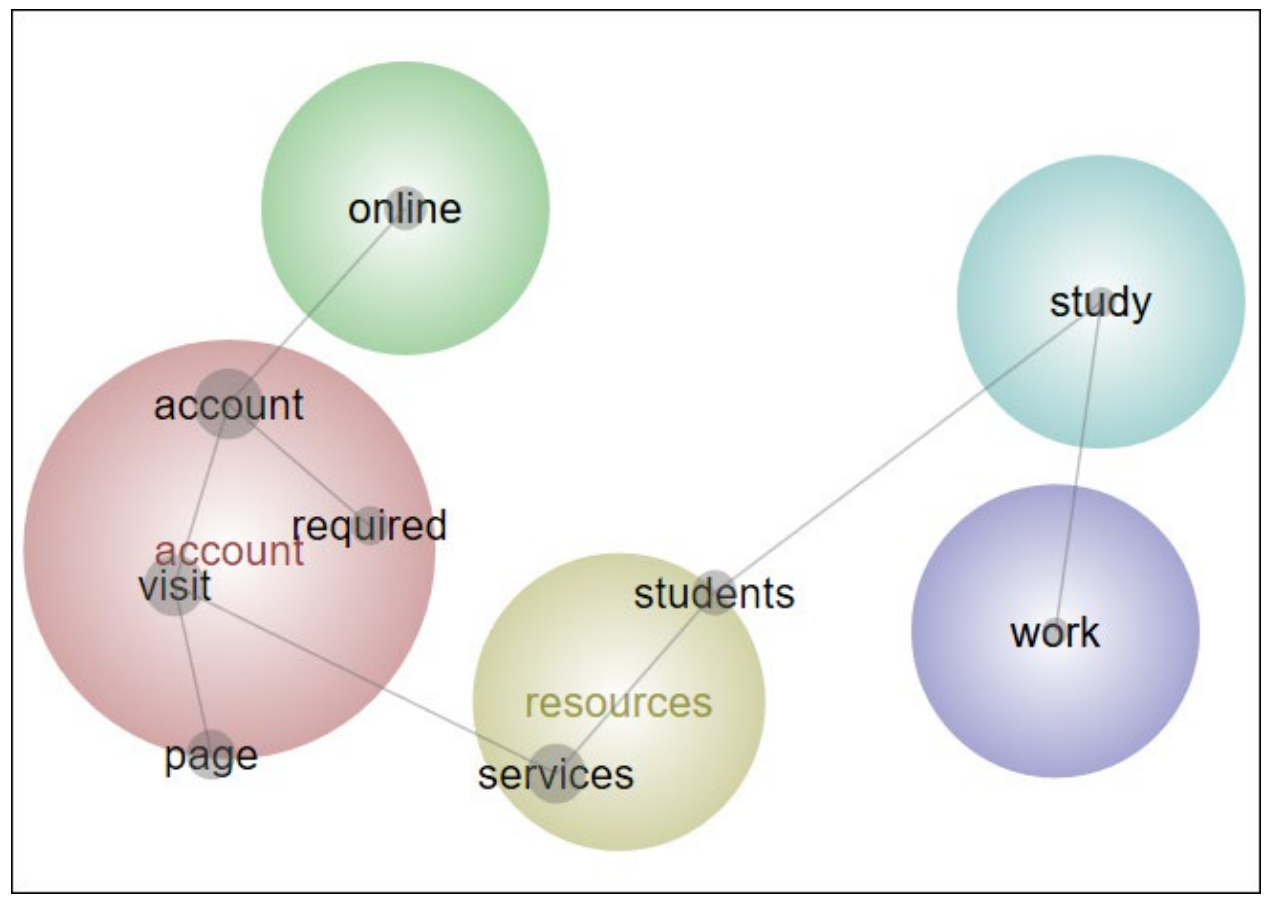

The narrative illustrations of the major themes from the database is presented in Table 21 .

Table 21: Narrative illustrations of the themes

\begin{tabular}{|c|c|}
\hline Theme & Narrative illustrations of the dataset \\
\hline account & "You are entitled to a concession fare ......." \\
\hline resources & $\begin{array}{l}\text { "Please refer page 81- Learn about the wide range of support services" } \\
\text { "Please refer to-"The Department of Home Affairs" }\end{array}$ \\
\hline online & $\begin{array}{l}\text { "[CITY] Metro's official app now available for Android \& with Nearby Stops } \\
\text { mode......" }\end{array}$ \\
\hline study & "Please refer: Education providers......." \\
\hline work & "Please refer: www.seek.com.au. \\
\hline
\end{tabular}

Figure 15 presents "account" as the major theme. Further investigation shows that the "account" theme provides travel-related information. The second major theme, "resources" is common and consists of information links to information pages for supporting services and facilities. The same information regarding travel is repeated in this section, emphasizing the repetition of the links in the web pages of the universities with negative international student enrolments. Other than the travel information, these webpages consist of information on visa details using related links such as "The Department of Home Affairs". The next theme "online" presents the webpage structure of certain applications (apps). The least significant theme "study" is significant in both universities with positive and 
negative international student enrolments. The themes "study" and "work" provide information on quality levels and recognition of courses, with external links to employment websites for finding employment.

\section{Discussion and conclusion}

The first major finding was that university websites with positive international student enrolments are more people focused and the university websites with negative international student enrolments are more system or technology focused. In the university websites with positive international student enrolments, the engagement of staff members was high. Most of the illustrative narrations listed the contact details of the different departments and of staff members. It has been found that people orientation is a major requirement for university websites aimed at enhancing the image of the university (Mentes \& Turan, 2012). The second major finding is that university websites with positive international student enrolments are forward looking as the university websites focus more on future students. University websites with negative international student enrolments are more backward looking by focusing past and current students. The number of studies with a future focus website feature as a major finding in education literature is limited. Moreover, internet or website strategies, as part of marketing strategies, are not well-explored in the literature relating to the university context. A synopsis of the overall findings of the university websites based on the level 2 analysis is provided in Table 22.

Table 22: Synopsis of the overall findings (similarities and differences) among university websites based on level 2 analysis

\begin{tabular}{|c|c|c|}
\hline Framework & Findings of website features for & Findings of website features for institutions \\
\hline variables & institutions with positive enrolments & with negative enrolments \\
\hline Information & $\begin{array}{l}\text {-Provides information on all the } \\
\text { study }\end{array}$ & - Focuses is more on postgraduate and \\
\hline \multirow[t]{2}{*}{ dimension } & programs & research degrees \\
\hline & -Focuses on future students & -Focuses on current and past students \\
\hline Communication & -Engages staff members in & - Lacks engagement with staff members in \\
\hline \multirow[t]{5}{*}{ dimension } & communication aspect & communication aspect \\
\hline & -Customizes options and filtering & - Customization is not significant \\
\hline & options & \\
\hline & - Communicates on all the study & -Communicates more on postgraduate \\
\hline & programs & degrees \\
\hline Transaction & - Engages staff members for & - Engagement of staff members for website \\
\hline \multirow[t]{3}{*}{ dimension } & website transactions & transactions is not significant \\
\hline & - Provides general transaction advice & $\begin{array}{l}\text {-Only provides general transaction advice } \\
\text { on }\end{array}$ \\
\hline & on resource & resources \\
\hline Relationship & -Customize and filtering options for & -Customize and filtering options for \\
\hline
\end{tabular}




\begin{tabular}{|c|c|c|}
\hline \multirow[t]{7}{*}{ dimension } & relationship attributes & relationship attributes \\
\hline & - More online facilities such as self- & - Online application facility only \\
\hline & enrolment facilities, self-credit and & \\
\hline & admissions assessment facilities & \\
\hline & - Gives more priority to & -Gives less priority to support \\
\hline & support from staff members in & from staff members in relationship aspect \\
\hline & relationship aspect & \\
\hline $\begin{array}{l}\text { Technical } \\
\text { merits }\end{array}$ & -Lacks links for certain & -Provides links for certain apps \\
\hline \multirow[t]{4}{*}{ dimension } & applications (apps) & \\
\hline & -Lack focus on employment & $\begin{array}{l}\text {-Provides links for employment websites } \\
\text { and }\end{array}$ \\
\hline & websites and other external websites & other external websites, videos, online tools \\
\hline & videos, online tools and social media & and social media \\
\hline
\end{tabular}

\subsection{Forward looking vs backward looking}

The level 2 analysis reports two major findings. First, similar to the level 1 analysis, the level 2 findings also show that university websites with positive international student enrolments are people focused and university websites with negative international student enrolments are system or technology focused. A study conducted by Rahnemai et al. (2015) evaluates the efficiency of Iranian official tourism websites from a functional perspective and regarding the role of tourism websites in urban development. The main aims of the study were fulfilled by content analysis of two official urban tourism websites. The results demonstrate that the websites were not successful in supporting to the Iranian Tourism Industry as it focuses only on the basic requirements through the information and communication dimensions (Rahnemai et al., 2015). It lacks advance options in transaction and relationship dimensions and reveals a converse correlation among complexity and performance of the websites (Rahnemai et al., 2015). The second major finding is that university websites with positive international student enrolments are forward looking with more focus on future students, and university websites with negative international student enrolments are more backward looking with more focus on past and current students. A study based on the top 10 world university websites' marketing strategies found a strong relationship between future oriented attributes of the websites and consumer choice (Nejati, Shafaei, Salamzadeh, \& Daraei, 2011).

\subsection{People focus vs system focus}


The most significant finding about the university websites with positive international student enrolments is their people focus and, for the university websites with negative international student enrolments, is their system or technology focus. In the university websites with positive international student enrolments, the engagement of staff members is high. Most of the illustrative narrations listed the contact details of the departments and of staff members. It has been found that people orientation is a major requirement for university websites that aim to enhance the image of the university (Mentes \& Turan, 2012).

In contrast, technology or system focus website features create a disadvantage for the service sector firms as more interactive website features and technology gradually limit the human interaction (Lipnack \& Stamps, 2008). A study conducted by Goodman (2003) finds that electronic communication is different from face to face conversations due to the differences between cyberspace and the physical world. Further, he mentions that service sector websites that engage with online services only offer two options to the customers either accept or decline the offer. The lack of interaction and customization affects the number of customers (Goodman, 2003).

\section{Theoretical and practical implications}

This study used ICTRT framework to evaluate the websites of Australian universities. Li and Wang (2011) proposed this framework for evaluating websites. Hotel, travel agency and destination marketing organization websites have been assessed using the ICTRT framework (Li \& Wang, 2011; Pai et al., 2014; Sun et al., 2017). This model has not previously been used, however, to evaluate tertiary education websites. This study is among the first to examine the university websites using a theoretical framework employed in destination marketing organizations which is a major theoretical contribution. The major findings indicate that the website attributes, which are future focused and people oriented, are necessary for university websites with negative international student enrolments. Therefore, similar to university websites with positive international student enrolments, university websites with negative international student enrolments should also provide more contact details of staff members, should be more people oriented and also should provide information focused on future students rather than past and current students. These practical implications are useful for administrative bodies in Australian universities for increasing international student enrolments.

\section{Limitations and future research perspectives}

This study has limitations due to the lack of well-defined structure and protocols as this is a cross 
sectional case study and not a longitudinal study (Yin, 1999). In this study, the researcher mitigated this limitation by using the conceptual framework of the ICTRT to collect and analyze the data that provides a proper structure. The relationship between the rate of website clicks and student enrolments is not considered in this study because this study used the ICTRT model as the conceptual framework and qualitative thematic data analysis method. The major two findings are derived from level 1 and level 2 analysis, that is, people-oriented vs system focused and forwardlooking vs backward looking. These findings should be further investigated and should be analyzed to find out the impact of the relationship on international student enrolments and institutional websites.

\section{Conclusion}

The university websites are the main source to learn more about the institutions of higher education. Therefore, it is considered as an essential element in a successful marketing practice (Carnevale, 2005). It is reported that more than $84 \%$ of students consider websites as a widespread marketing tool and widespread medium for student inquiries (NACAC, 2011).Therefore, this study explored the relationship between institutional websites on international student enrolments. This research fulfilled some of the existing gaps in the Australian Higher Education industry based on international students which are: few marketing research on international student recruitment strategies focused tertiary education institutes with less studies focusing the country Australia and none of the studies applied the ICTRT framework to assess the university websites. This is the first study, to apply this framework in the education context. The two significant findings were that university websites with positive international student enrolments are people focused (more interaction with staff) and website content is more future focused whereas university websites with negative international student enrolments are system or technology focused and content is not updated and backward looking. 


\section{References}

A1, P. N., \& Carmen, A. (2011). A qualitative research regarding the marketing communication tools used in the online environment. European integration-New Challenges, 1898.

Blackwell, A., Bowes, L., Harvey, L., Hesketh, A. J., \& Knight, P. T. (2001). Transforming work experience in higher education. British Educational research journal, 27(3), 269-285.

Bodycott, P. (2009). Choosing a higher education study abroad destination: What mainland Chinese parents and students rate as important. Journal of research in International education, 8(3), 349-373.

Böhm, A., Follari, M., Hewett, A., Jones, S., Kemp, N., Meares, D., . . Cauter, K. V. (2003). Forecasting international student mobility a UK perspective.

Bohm, A., Follari, M., Hewett, A., Jones, S., Kemp, N., Meares, D., . . Van Cauter, K. (2004). Forecasting international student mobility: A UK perspective. London: British Council.

Brown, R. M., \& Mazzarol, T. W. (2009). The importance of institutional image to student satisfaction and loyalty within higher education. Higher Education, 58(1), 81-95.

Carnevale, D. (2005). To size up colleges, students now shop online. Chronicle of Higher Education, 51(40), A25.

Chapleo, C., Carrillo Durán, M. V., \& Castillo Díaz, A. (2011). Do UK universities communicate their brands effectively through their websites? Journal of Marketing for Higher Education, 21(1), 25-46.

Charoula, D., Eleonora-Ioulia, M., Fotini, P., \& Maro, V. (2014). Evaluating destination marketing organizations' websites: Conceptual and empirical review. Evaluating Websites and Web Services: Interdisciplinary Perspectives on User Satisfaction, 1, $72-$ 84.

Creswell, J. W., \& Clark, V. L. P. (2007). Designing and conducting mixed methods research.

Doolin, B., Burgess, L., \& Cooper, J. (2002). Evaluating the use of the Web for tourism marketing: a case study from New Zealand. Tourism management, 23(5), 557-561.

Gatfield, T., Barker, M., \& Graham, P. (1999). Measuring communication impact for university advertising materials. Corporate Communications: An International Journal, 4(2), 73-79.

Gomes, L., \& Murphy, J. (2003). An exploratory study of marketing international education online. International Journal of Educational Management, 17(3), 116-125.

Goodman, J. W. (2003). The pros and cons of online dispute resolution: an assessment of cybermediation websites. Duke Law \& Technology Review, 2(1), 1-16.

Gray, B., Fam, K., \& Llanes, V. (2003). Cross cultural values and the positioning of international education brands. Journal of Product and Brand Management, 12(2), 108-119.

Harman, G. (2001). Impact of the NPM on higher education reform in Australia. In Public Sector Reform (pp. 151-166): Springer.

Hemsley-Brown, J., \& Oplatka, I. (2006). Universities in a competitive global marketplace: A systematic review of the literature on higher education marketing. International journal of public sector management, 19(4), 316-338.

Hossler, D. (2005). Refinancing public universities. Public funding of higher education: Changing contexts and new rationales, 145-163.

Howe, E. R. (2009). The internationalization of higher education in East Asia: A comparative ethnographic narrative of Japanese universities. Research in Comparative and International Education, 4(4), 384-392. 
Huang, I. Y., Raimo, V., \& Humfrey, C. (2016). Power and control: managing agents for international student recruitment in higher education. Studies in Higher Education, 41(8), 1333-1354.

Isa, F. M., Othman, S. N., \& Muhammad, N. M. N. (2016). Postgraduate Students' Recruitment Strategies in Higher Education Institutions of Malaysia. International Review of Management and Marketing, 6(8S).

José, M. C., Joaquín, S., \& Julio, C. (2006). International students' decision-making process. International Journal of Educational Management, 20(2), 101-115. doi:doi:10.1108/09513540610646091

Kasper, H. (2002). Culture and leadership in market-oriented service organisations. European journal of marketing, 36(9/10), 1047-1057.

Klassen, M. L. (2002). Relationship marketing on the Internet: the case of top-and lower-ranked US universities and colleges. Journal of Retailing and Consumer Services, 9(2), 81-85.

Kotler, P. (2011). Philip Kotler's contributions to marketing theory and practice. In Review of Marketing Research: Special Issue-Marketing Legends (pp. 87-120): Emerald Group Publishing Limited.

Lacey, J. (2016). More colleges use Facebook to recruit students http://chronicle.com/blogs/headcount/more-colleges-usefacebook-to-recruitstudents/29366.

Law, R., \& Hsu, C. H. (2005). Customers' perceptions on the importance of hotel web site dimensions and attributes. International Journal of Contemporary Hospitality Management, 17(6), 493-503.

Li, G., Chen, W., \& Duanmu, J.-L. (2010). Determinants of international students' academic performance: A comparison between Chinese and other international students. Journal of Studies in International Education, 14(4), 389-405.

Li, X., \& Wang, Y. (2010). Evaluating the effectiveness of destination marketing organisations' websites: evidence from China. International journal of tourism research, 12(5), 536549.

Li, X., \& Wang, Y. (2011). Is your official state tourism website effective? A functional perspective.

Lipnack, J., \& Stamps, J. (2008). Virtual teams: People working across boundaries with technology: John Wiley \& Sons.

Long, C. S., Kowang, T. O., \& Fei, G. C. (2018). Website Quality of the Travel Agencies in Malaysia. Business Management and Strategy, 9(1), 114-135.

Mairaj, M. I. (2016). Use of university's library websites in Pakistan: an evaluation. Pakistan Journal of Information Management \& Libraries (PJIM\&L), 14.

Mandel, M. J., Hof, R. D., Foust, D., \& Muller, J. (2001). Rethinking the internet. Business Week(3725), 116-116.

Manganari, E. E., Siomkos, G. J., Rigopoulou, I. D., \& Vrechopoulos, A. P. (2011). Virtual store layout effects on consumer behaviour: applying an environmental psychology approach in the online travel industry. Internet Research, 21(3), 326-346.

Marginson, S., \& Van der Wende, M. (2007). To rank or to be ranked: The impact of global rankings in higher education. Journal of studies in international education, 11(3-4), 306329.

Matthews, D. (2012). Grand fee paid for each foreign student. Times Higher Education, 5. 
Mazzarol, T., Norman Soutar, G., \& Sim Yaw Seng, M. (2003). The third wave: Future trends in international education. International Journal of Educational Management, 17(3), 90-99.

Mazzarol, T., \& Soutar, G. N. (2002). "Push-pull" factors influencing international student destination choice. International Journal of Educational Management, 16(2), 82-90.

Mentes, S. A., \& Turan, A. H. (2012). Assessing the usability of university websites: An empirical study on Namik Kemal University. Turkish Online Journal of Educational Technology-TOJET, 11(3), 61-69.

Minde, M., \& Jani, D. (2016). A comparative analysis of East African destination marketing organizations' websites. International Journal of Tourism Sciences, 16(1-2), 15-26.

Moore, S., \& Seymour, M. (2005). Global technology and corporate crisis: Strategies, planning and communication in the information age: Taylor \& Francis.

Morrison, A. M., Taylor, J. S., \& Douglas, A. (2005). Website evaluation in tourism and hospitality: the art is not yet stated. Journal of Travel \& Tourism Marketing, 17(2-3), 233-251.

Mortimer, K. (2008). Identifying the components of effective service advertisements. Journal of Services marketing, 22(2), 104-113.

Mukhopadhyay, R. S., Waller, A., \& Franklin, V. L. (2008). What do UK children's hospital websites offer patients and families? Archives of disease in childhood, 93(2), 179-180.

NACAC. (2011). State of College Admission Report, Arlington, VA. National Association for College Admission Counseling.

Naidoo, V. (2006). International education: A tertiary-level industry update. Journal of research in international education, 5(3), 323-345.

Oplatka, I., \& Hemsley-Brown, J. (2004). The research on school marketing: Current issues and future directions. Journal of educational administration, 42(3), 375-400.

Ozturgut, O. (2013). Best practices in recruiting and retaining international students in the US. Current Issues in Education, 16(2).

Pai, C.-K., Xia, M. L., \& Wang, T.-W. (2014). A comparison of the official tourism website of five east tourism destinations. Information Technology \& Tourism, 14(2), 97-117.

Park, Y. A., \& Gretzel, U. (2007). Success factors for destination marketing web sites: A qualitative meta-analysis. Journal of Travel Research, 46(1), 46-63.

Pimpa, N. (2001). The influence of family, peers, and education agents on Thai students' choices of international education. Paper presented at the 15th Australian Internafional Educafion Conference.

Pimpa, N. (2003). The influence of family on Thai students' choices of international education. International Journal of Educational Management, 17(5), 211-219.

Rahnemai, M. T., Rezvani, M. R., Rahimpour, A., \& Jafari, F. (2015). Evaluation of Tourism Websites from Urban Development Perspective (Case Study: Metropolitan Tehran). International Journal of Architecture and Urban Development, 5(4), 59-66.

Raymond, L. (2001). Determinants of web site implementation in small businesses. Internet Research, 11(5), 411-424.

Sabaruddin, S. A., Abdullah, N. H., \& Jamal, S. A. (2012). An Evaluation of the Homestay Tourism Website in Promoting Heritage Tourist Attractions. Penerbit UiTM, 31.

Saunders, M., Lewis, P., \& Thornhill, A. (2009). Research methods for business students: Pearson education. 
Sekaran, U., \& Bougie, R. (2016). Research methods for business: A skill building approach: John Wiley \& Sons.

Smith, J., \& Firth, J. (2011). Qualitative data analysis: the framework approach. Nurse researcher, 18(2), 52-62.

Sun, S., Fong, D. K. C., Law, R., \& He, S. (2017). An updated comprehensive review of website evaluation studies in hospitality and tourism. International Journal of Contemporary Hospitality Management, 29(1), 355-373.

Sweeney, J. C., Soutar, G. N., \& Mazzarol, T. (2008). Factors influencing word of mouth effectiveness: receiver perspectives. European Journal of Marketing, 42(3/4), 344-364.

Tang, T. (2011). Marketing higher education across borders: a cross-cultural analysis of university websites in the US and China. Chinese Journal of Communication, 4(4), 417429.

Tracy. (2012). Qualitative Research Methods: Collecting Evidence, Crafting Analysis, Communicating Impact: Wiley.

Wang. (2009). Institutional recruitment strategies and international undergraduate student university choice at two Canadian universities.

Wang, X. (2009). Institutional recruitment strategies and international undergraduate student university choice at two Canadian universities.

Wang, Y., \& Russo, S. M. (2007). Conceptualizing and evaluating the functions of destination marketing systems. Journal of Vacation Marketing, 13(3), 187-203.

Yannacopoulos, D. (2014). Evaluating Websites and Web Services: Interdisciplinary Perspectives on User Satisfaction: Interdisciplinary Perspectives on User Satisfaction: IGI Global.

Yin, R. K. (1999). Enhancing the quality of case studies in health services research. Health services research, 34(5 Pt 2), 1209. 


\section{Appendices}

Selection of the respective university websites for the study - The international student enrolment data is obtained through Higher Education Statistics data base (uCube) ${ }^{3}$. Out of the 43 universities in Australia six university websites been selected for this study considering the state, undergraduate and postgraduate percentage change of international student enrolments during a time period of six-years (2011 to 2016).

Table A: International postgraduate student enrolment and percentage change in enrolment between 2011 and 2016 in Australian Universities

\begin{tabular}{|c|c|c|c|c|c|c|c|c|c|c|c|c|}
\hline University & 2011 & 2012 & $\begin{array}{l}\begin{array}{l}\% \\
\text { change } \\
2011- \\
2012\end{array} \\
\end{array}$ & 2013 & $\begin{array}{l}\% \\
\text { change } \\
2012- \\
2013 \\
\end{array}$ & 2014 & $\begin{array}{l}\% \\
\text { change } \\
2013- \\
2014 \\
\end{array}$ & 2015 & $\begin{array}{l}\% \\
\text { change } \\
2014- \\
2015 \\
\end{array}$ & 2016 & $\begin{array}{l}\begin{array}{l}\% \\
\text { change } \\
2015- \\
2016\end{array} \\
\end{array}$ & $\begin{array}{l}\begin{array}{l}\% \\
\text { change } \\
2012- \\
2016\end{array} \\
\end{array}$ \\
\hline Charles Darwin University & 314 & 333 & 6.05 & 437 & 31.23 & 831 & 90.16 & 1065 & 28.15 & 1270 & 19.24 & 281.38 \\
\hline The University of Sydney & 5464 & 5283 & -3.31 & 6041 & 14.34 & 7349 & 21.65 & 9120 & 24.09 & 11419 & 25.20 & 116.14 \\
\hline University of Technology Sydney & 5464 & 5283 & -3.31 & 6041 & 14.34 & 7349 & 21.65 & 9120 & 24.09 & 11419 & 25.20 & 116.14 \\
\hline Monash University & 5497 & 5647 & 2.72 & 6264 & 10.92 & 7826 & 24.93 & 9198 & 17.53 & 10951 & 19.05 & 93.92 \\
\hline Deakin University & 3132 & 2968 & -5.23 & 3200 & 7.81 & 3813 & 19.15 & 4253 & 11.53 & 4785 & 12.50 & 61.21 \\
\hline $\begin{array}{l}\text { The Australian National } \\
\text { University }\end{array}$ & 2981 & 3155 & 5.83 & 3490 & 10.61 & 3994 & 14.44 & 4055 & 1.52 & 4747 & 17.06 & 50.45 \\
\hline RMIT University & 4332 & 3949 & -8.84 & 3987 & 0.96 & 4569 & 14.59 & 5015 & 9.76 & 5609 & 11.84 & 42.03 \\
\hline University of Tasmania & 1270 & 1374 & 8.18 & 1287 & -6.33 & 1423 & 10.56 & 1712 & 20.30 & 1925 & 12.44 & 40.10 \\
\hline Flinders University & 2239 & 2345 & 4.73 & 2648 & 12.92 & 2860 & 8.00 & 3199 & 11.85 & 3206 & 0.21 & 36.71 \\
\hline $\begin{array}{l}\text { The University of Western } \\
\text { Australia }\end{array}$ & 1884 & 1664 & -11.67 & 1530 & -8.05 & 1568 & 2.48 & 1754 & 11.86 & 2155 & 22.86 & 29.50 \\
\hline The University of Queensland & 5089 & 5141 & 1.021 & 5200 & 1.147 & 5396 & 3.76 & 5831 & 8.06 & 6498 & 11.43 & 26.39 \\
\hline $\begin{array}{l}\text { Swinburne } \quad \text { University } \\
\text { Technology }\end{array}$ & 2856 & 2455 & -14.04 & 2424 & -1.26 & 2752 & 13.53 & 2892 & 5.08 & 3090 & 6.84 & 25.86 \\
\hline $\begin{array}{l}\text { Queensland University of } \\
\text { Technology }\end{array}$ & 2791 & 2783 & -0.28 & 2928 & 5.21 & 3477 & 18.75 & 3461 & -0.46 & 3166 & -8.52 & 13.76 \\
\hline Curtin University of Technology & 3724 & 3423 & -8.08 & 3342 & -2.36 & 3534 & 5.74 & 3871 & 9.53 & 3669 & -5.21 & 7.18 \\
\hline Australian Catholic University & 627 & 604 & -3.66 & 569 & -5.79 & 621 & 9.13 & 633 & 1.93 & 645 & 1.89 & 6.78 \\
\hline Griffith University & 3187 & 2914 & -8.56 & 2792 & -4.18 & 3010 & 7.80 & 2820 & -6.31 & 2833 & 0.46 & -2.77 \\
\hline
\end{tabular}

\footnotetext{
${ }^{3} \mathrm{http}: / /$ highereducationstatistics.education.gov.au/
} 


\begin{tabular}{|c|c|c|c|c|c|c|c|c|c|c|c|c|}
\hline James Cook University & 2115 & 2281 & 7.84 & 2636 & 15.56 & 2779 & 5.42 & 2487 & -10.50 & 2211 & -11.09 & -3.06 \\
\hline $\begin{array}{l}\text { University of } \quad \text { Southern } \\
\text { Queensland }\end{array}$ & 2916 & 2827 & -3.05 & 2452 & -13.26 & 2616 & 6.68 & 2745 & 4.93 & 2616 & -4.69 & -7.46 \\
\hline Victoria University & 2212 & 2124 & -3.97 & 2038 & -4.04 & 2226 & 9.22 & 2017 & -9.38 & 1929 & -4.36 & -9.18 \\
\hline University of Canberra & 1529 & 1536 & 0.45 & 1468 & -4.42 & 1488 & 1.36 & 1466 & -1.47 & 1367 & -6.75 & -11.00 \\
\hline University of South Australia & 2537 & 2266 & -10.68 & 2043 & -9.84 & 1984 & -2.88 & 1964 & -1.00 & 1984 & 1.01 & -12.44 \\
\hline The University of Newcastle & 2466 & 2579 & 4.58 & 2637 & 2.24 & 2443 & -7.35 & 2187 & -10.47 & 2208 & 0.96 & -14.38 \\
\hline Murdoch University & 969 & 1285 & 32.61 & 1238 & -3.65 & 1188 & -4.03 & 1184 & -0.33 & 1088 & -8.10 & -15.33 \\
\hline University of Wollongong & 5,128 & 4,991 & -2.67 & 5,328 & 6.75 & 5,746 & 7.84 & 5,446 & -5.22 & 5,690 & 4.48 & 14.00 \\
\hline University of Melbourne & 4,679 & 5,943 & 27.01 & 7,346 & 23.60 & 9,034 & 22.97 & 10,355 & 14.62 & 11,867 & 14.60 & 99.68 \\
\hline University of New England & 927 & 839 & -9.49 & 607 & -27.65 & 568 & -6.42 & 589 & 3.69 & 686 & 16.46 & -18.23 \\
\hline $\begin{array}{l}\text { University of Notre Dame } \\
\text { Australia }\end{array}$ & 97 & 83 & -14.43 & 38 & -54.21 & 36 & -5.26 & 40 & 11.11 & 45 & 12.5 & -45.78 \\
\hline Charles Sturt University & 1784 & 1989 & 11.49 & 2530 & 27.19 & 3594 & 42.05 & 4671 & 29.96 & 6428 & 37.61 & 223.18 \\
\hline Southern Cross University & 682 & 645 & -5.43 & 568 & -11.94 & 767 & 35.03 & 893 & 16.43 & 1141 & 27.78 & 76.89 \\
\hline Macquarie University & 4377 & 4252 & -2.94 & 4471 & 5.15 & 4426 & -1.01 & 4115 & -7.03 & 4484 & 8.97 & 5.46 \\
\hline University of New South Wales & 6082 & 5969 & -1.86 & 6049 & 1.34 & 6387 & 5.59 & 7012 & 9.78 & 8493 & 21.12 & 42.29 \\
\hline University of Western Sydney & 2125 & 1985 & -6.59 & 2091 & 5.34 & 2301 & 10.04 & 2109 & -8.34 & 2108 & -0.04 & 6.19 \\
\hline Bond University & 1176 & 1190 & 1.19 & 1154 & -3.03 & 1270 & 10.05 & 1295 & 1.97 & 1455 & 12.36 & 22.27 \\
\hline University of the Sunshine Coast & 316 & 253 & -19.94 & 356 & 40.71 & 533 & 49.72 & 494 & -7.32 & 846 & 71.26 & 234.39 \\
\hline CQ University & 3492 & 2699 & -22.71 & 2615 & -3.11 & 3226 & 23.37 & 3797 & 17.69 & 4140 & 9.03 & 53.39 \\
\hline University of Adelaide & 3017 & 2996 & -0.69 & 3053 & 1.90 & 3213 & 5.24 & 3343 & 4.04 & 3431 & 2.63 & 14.52 \\
\hline Torrens University Australia & NA & NA & NA & NA & NA & NA & NA & 248 & NA & 1284 & 417.74 & NA \\
\hline Federation University of Australia & 2632 & 2481 & -5.74 & 2885 & 16.28 & 3504 & 21.46 & 3697 & 5.50 & 2583 & -30.13 & 4.11 \\
\hline La Trobe University & 2941 & 2912 & -0.98 & 3166 & 8.72 & 3681 & 16.27 & 3673 & -0.22 & 3895 & 6.04 & 33.76 \\
\hline Edith Cowan University & 2007 & 1655 & -17.54 & 1446 & -12.63 & 1558 & 7.75 & 1964 & 26.06 & 2586 & 31.67 & 56.25 \\
\hline University of Divinity & 51 & 68 & 33.33 & 78 & 14.71 & 64 & -17.95 & 69 & 7.81 & 78 & 13.04 & 14.71 \\
\hline University College London & NA & NA & NA & NA & NA & NA & NA & NA & NA & NA & NA & NA \\
\hline Carnegie Mellon University & NA & NA & NA & NA & NA & NA & NA & NA & NA & NA & NA & NA \\
\hline
\end{tabular}


Table B: International undergraduate student enrolment and percentage change in enrolment between 2011 to 2016 in Australian Universities

\begin{tabular}{|c|c|c|c|c|c|c|c|c|c|c|c|c|}
\hline University & 2011 & 2012 & $\begin{array}{l}\% \\
\text { change } \\
2011- \\
2012\end{array}$ & 2013 & $\begin{array}{l}\% \\
\text { change } \\
2012- \\
2013\end{array}$ & 2014 & $\begin{array}{l}\% \\
\text { change } \\
2013- \\
2014\end{array}$ & 2015 & $\begin{array}{l}\% \\
\text { change } \\
2014- \\
2015\end{array}$ & 2016 & $\begin{array}{l}\% \\
\text { change } \\
2015- \\
2016\end{array}$ & $\begin{array}{l}\begin{array}{l}\% \\
\text { change } \\
2012- \\
2016\end{array} \\
\end{array}$ \\
\hline Charles Darwin University & 566 & 675 & 19.25 & 724 & 7.25 & 989 & 36.60 & 1379 & 39.43 & 1342 & -2.68 & 98.81 \\
\hline The University of Sydney & 5650 & 5518 & -2.33 & 5589 & 1.28 & 5651 & 1.10 & 6143 & 8.70 & 7098 & 15.54 & 28.63 \\
\hline University of Technology Sydney & 4588 & 4695 & 2.33 & 4745 & 1.06 & 4739 & -0.12 & 4961 & 4.68 & 5619 & 13.26 & 19.68 \\
\hline Monash University & 16988 & 16306 & -4.01 & 15533 & -4.74 & 15472 & -0.39 & 16541 & 6.90 & 18181 & 9.91 & 11.49 \\
\hline Deakin University & 5091 & 4654 & -8.58 & 3975 & -14.58 & 3715 & -6.54 & 4061 & 9.31 & 4627 & 13.93 & -0.58 \\
\hline $\begin{array}{l}\text { The Australian National } \\
\text { University }\end{array}$ & 2290 & 2158 & -5.76 & 1953 & -9.49 & 1989 & 1.84 & 2140 & 7.59 & 2611 & 22.00 & 20.99 \\
\hline RMIT University & 22622 & 22532 & -0.39 & 22411 & -0.53 & 21822 & -2.62 & 21244 & -2.64 & 21477 & 1.09 & -4.68 \\
\hline University of Tasmania & 4371 & 4017 & -8.09 & 3585 & -10.75 & 3386 & -5.55 & 3625 & 7.058 & 3477 & -4.08 & -13.44 \\
\hline Flinders University & 1427 & 1347 & -5.60 & 1140 & -15.36 & 1203 & 5.52 & 1227 & 1.99 & 1369 & 11.57 & 1.63 \\
\hline $\begin{array}{l}\text { The University of Western } \\
\text { Australia }\end{array}$ & 3805 & 3759 & -1.20 & 3711 & -1.27 & 3639 & -1.94 & 2998 & -17.61 & 2745 & -8.43 & -26.97 \\
\hline The University of Queensland & 5680 & 5698 & 0.31 & 5694 & -0.070 & 5840 & 2.56 & 6010 & 2.91 & 6282 & 4.52 & 10.24 \\
\hline $\begin{array}{l}\text { Swinburne University of } \\
\text { Technology }\end{array}$ & 6341 & 6809 & 7.38 & 6160 & -9.53 & 5673 & -7.90 & 5592 & -1.42 & 5777 & 3.30 & -15.15 \\
\hline $\begin{array}{l}\text { Queensland University of } \\
\text { Technology }\end{array}$ & 4077 & 4205 & 3.13 & 4144 & -1.45 & 4048 & -2.31 & 4114 & 1.63 & 4199 & 2.06 & -0.14 \\
\hline Curtin University of Technology & 14135 & 12980 & -8.17 & 12056 & -7.11 & 11671 & -3.19 & 11327 & -2.94 & 10751 & -5.08 & -17.17 \\
\hline Australian Catholic University & 2807 & 2366 & -15.71 & 1996 & -15.63 & 2014 & 0.90 & 2179 & 8.19 & 2207 & 1.28 & -6.72 \\
\hline Griffith University & 7167 & 6442 & -10.11 & 5733 & -11.00 & 5422 & -5.42 & 5276 & -2.69 & 5059 & -4.11 & -21.46 \\
\hline James Cook University & 3107 & 3388 & 9.04 & 3442 & 1.59 & 3432 & -0.29 & 3193 & -6.96 & 3199 & 0.18 & -5.57 \\
\hline $\begin{array}{l}\text { University of Southern } \\
\text { Queensland }\end{array}$ & 2692 & 2593 & -3.67 & 2248 & -13.30 & 1932 & -14.05 & 1410 & -27.01 & 995 & -29.43 & -61.62 \\
\hline Victoria University & 5,114 & 5,201 & 1.70 & 6,859 & 31.87 & 7,677 & 11.92 & 7,210 & -6.08 & 7,017 & -2.67 & 34.91 \\
\hline University of Canberra & 2267 & 2324 & 2.51 & 2165 & -6.84 & 2464 & 13.81 & 2467 & 0.12 & 2299 & -6.80 & -1.07 \\
\hline University of South Australia & 7496 & 6293 & -16.04 & 5223 & -17.00 & 4100 & -21.50 & 3603 & -12.12 & 3485 & -3.27 & -44.62 \\
\hline The University of Newcastle & 3219 & 3079 & -4.34 & 2995 & -2.72 & 2895 & -3.33 & 2760 & -4.66 & 2713 & -1.70 & -11.88 \\
\hline Murdoch University & 5,223 & 7,282 & 39.42 & 8,440 & 15.90 & 8,773 & 3.94 & 8,553 & -2.50 & 8,131 & -4.93 & 11.65 \\
\hline
\end{tabular}




\begin{tabular}{|c|c|c|c|c|c|c|c|c|c|c|c|c|}
\hline University of Wollongong & 5,040 & 5,649 & 12.08 & 6,357 & 12.53 & 6,683 & 5.12 & 6,959 & 4.12 & 7,415 & 6.55 & 31.26 \\
\hline University of Melbourne & 6,824 & 6,481 & -5.02 & 6,311 & -2.62 & 6,500 & 2.99 & 7,402 & 13.87 & 8,615 & 16.38 & 32.92 \\
\hline University of New England & 532 & 541 & 1.69 & 402 & -25.69 & 365 & -9.20 & 349 & -4.38 & 351 & 0.57 & -35.12 \\
\hline $\begin{array}{l}\text { University of Notre Dame } \\
\text { Australia }\end{array}$ & 261 & 184 & -29.50 & 139 & -24.45 & 117 & -15.82 & 101 & -13.67 & 89 & -11.88 & -51.63 \\
\hline Charles Sturt University & 3306 & 3255 & -1.54 & 3240 & -0.46 & 3253 & 0.40 & 2865 & -11.93 & 2351 & -17.94 & -27.77 \\
\hline Southern Cross University & 2521 & 2022 & -19.79 & 1360 & -3.74 & 1154 & -15.15 & 1272 & 10.22 & 1622 & 27.52 & -19.78 \\
\hline Macquarie University & 7569 & 6695 & -11.55 & 5143 & -23.18 & 4364 & -15.15 & 4074 & -6.65 & 4906 & 20.42 & -26.72 \\
\hline University of New South Wales & 6489 & 6394 & -1.46 & 6097 & -4.64 & 5896 & -3.29 & 6236 & 5.77 & 7268 & 16.55 & 13.67 \\
\hline University of Western Sydney & 2099 & 2131 & 1.52 & 2090 & -1.92 & 2236 & 6.99 & 2356 & 5.37 & 2563 & 8.78 & 24.49 \\
\hline Bond University & 764 & 664 & -13.09 & 554 & -16.57 & 493 & -11.01 & 497 & 0.82 & 498 & 0.20 & -25 \\
\hline University of the Sunshine Coast & 470 & 441 & -6.17 & 465 & 5.44 & 588 & 26.45 & 717 & 21.94 & 1216 & 69.59 & 175.74 \\
\hline CQ University & 3380 & 2705 & -19.97 & 1744 & -35.53 & 1211 & -30.56 & 921 & -23.95 & 799 & -13.25 & -70.46 \\
\hline University of Adelaide & 3772 & 3815 & 1.14 & 3445 & -9.69 & 3360 & -2.47 & 3476 & 3.45 & 3732 & 7.36 & -2.18 \\
\hline Torrens University Australia & NA & NA & NA & NA & NA & NA & NA & NA & NA & 1562 & NA & NA \\
\hline Federation University of Australia & 2980 & 3256 & 9.26 & 3038 & -6.69 & 3148 & 3.62 & 3385 & 7.53 & 3002 & -11.31 & -7.80 \\
\hline La Trobe University & 5552 & 5062 & -8.83 & 4361 & -13.85 & 4130 & -5.29 & 4243 & 2.74 & 4669 & 10.04 & -7.76 \\
\hline Edith Cowan University & 3500 & 3109 & -11.17 & 2779 & -10.61 & 2451 & -11.80 & 2306 & -5.92 & 2453 & 6.37 & -21.10 \\
\hline University of Divinity & 62 & 65 & 4.84 & 64 & -1.54 & 63 & -1.56 & 65 & 3.17 & 64 & -1.54 & -1.54 \\
\hline University College London & NA & NA & NA & NA & NA & NA & NA & NA & NA & NA & NA & NA \\
\hline Carnegie Mellon University & NA & NA & NA & NA & NA & NA & NA & NA & NA & NA & NA & NA \\
\hline
\end{tabular}

$\mathrm{NA}=$ Not available

As shown in the above Tables out of the these universities, a positive percentage variance appears to be in University A, B and C. Negative percentage trend appears to be in University D, E, and F. The constant percentage variance is disregarded due to the unavailability. Therefore, the websites of these six universities been selected for further investigation of this study. 
